\title{
PRIMĀRAS MUTES DOBUMA REKONSTRUKCIJAS AR MIKROVASKULĀRIEM LËVERIEM PACIENTIEM AR MUTES VĒZI VĒLĪNĀS STADIJĀS, IETEKME UZ PACIENTU DZĪVILDZI UN DZĪVES KVALITĀTI
}

Promocijas darba kopsavilkums medicinnas doktora zinātniskā grāda iegūšanai Specialitāte - plastikas ķirurǵija 


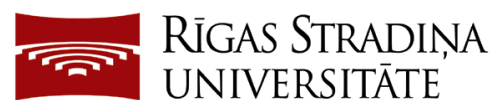

\author{
Kalvis Pastars
}

\title{
PRIMĀRAS MUTES DOBUMA REKONSTRUKCIJAS AR MIKROVASKULĀRIEM LĒVERIEM PACIENTIEM AR MUTES VĒZI VĒLINNĀS STADIJĀS, IETEKME UZ PACIENTU DZĪVILDZI UN DZĪVES KVALITĀTI
}

\author{
Promocijas darba kopsavilkums \\ medicīnas doktora zinātniskā grāda iegūšanai
}

Specialitāte - plastikas ķirurǵija

$$
\text { Rīga, } 2019
$$


Pētījums izstrādāts Rīgas Austrumu klīniskās universitātes slimnīcas Latvijas Onkolog̣ijas centrā (RAKUS LOC) sadarbībā ar Latvijas Plastiskās, rekonstruktīvās un mikroķirurg̣ijas centru. Pētījums apstiprināts Rīgas Stradiṇa universitātes Ētikas komitejas lēmumu 2014. gada 4. septembrī.

Darba zinātniskais vadītājs:

Dr. habil. med. profesors Andrejs Skaǵers,

RSU Mutes, sejas un žokḷu ḳirurǵijas katedra, Latvija

Oficiālie recenzenti:

Dr. med. asociētais profesors Jānis Eglītis，Latvijas Universitātes

Onkolog̣ijas katedra

Dr. habil. med. profesors Ričardas Kubilius,

LSMU Mutes, sejas un žokḷu k̦irurǵijas katedra, Lietuva

Dr. med. profesore Ingrīda Čēma,

RSU Mutes medicīnas katedra, Latvija

Promocijas darba aizstāvēšana notiks 2019. gada 10. jūlijā plkst. 14.00

Rīgas Stradinna universitātes Medicīnas promocijas padomes atklātā sēdē Rīgā, Dzirciema ielā 16, Hipokrāta auditorijā.

Ar promocijas darbu var iepazīties RSU bibliotēkā un RSU tīmekḷa vietnē: www.rsu.lv.

Promocijas padomes sekretāre:

Dr. med. docente Gunta Sumeraga 


\section{SATURS}

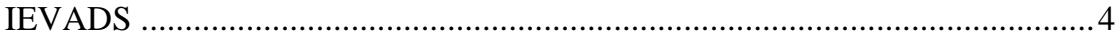

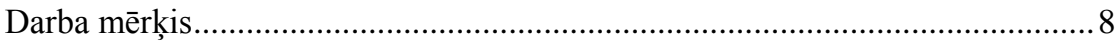

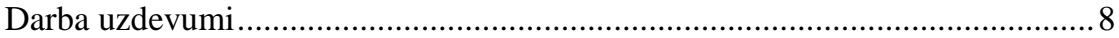

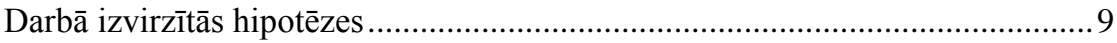

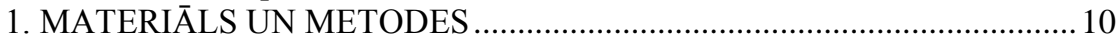

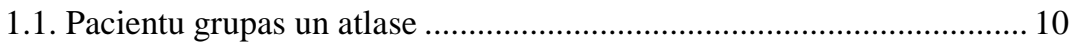

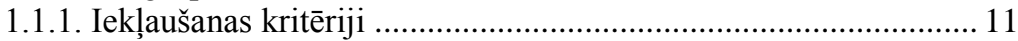

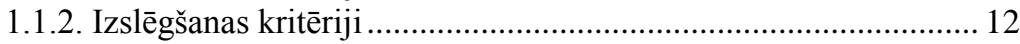

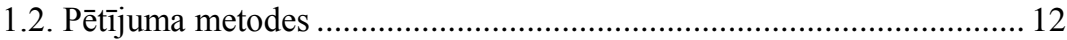

1.2.1. Dzīvildzes novērtēšanas metodika............................................. 13

1.2.2. Dzīves kvalitātes novērtēšanas metodika .................................. 13

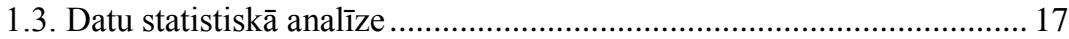

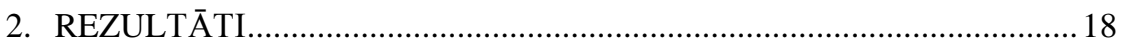

2.1. Slimnieku klīniskais un vēža patomorfologiskais raksturojums ......... 18

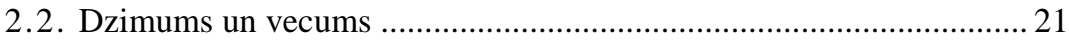

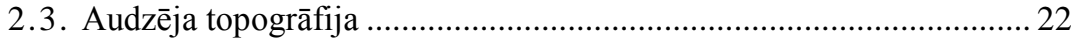

2.4. Klasifikācija pēc TNM sistēmas ..................................................... 23

2.5. Audzēja lokalizācijas saistība ar metastazēšanās biežumu kakla

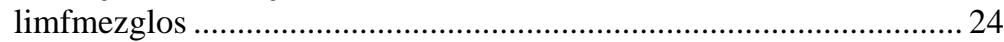

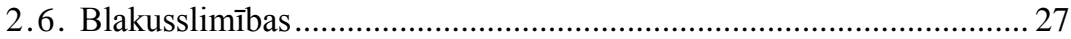

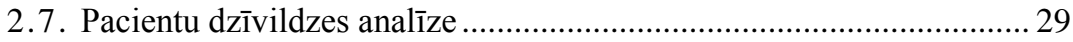

2.8. Dzīves kvalitātes novērtējums.......................................................... 31

2.9. Mikrovaskulās rekonstrukcijas metožu pielietojums ........................... 35

2.10. Pētījuma grupas pacientu stacionārā pavadītā laika analīze ................ 36

2.11. Pēcoperāciju komplikāciju analīze pētījuma grupā ........................... 37

2.12. Rekonstrukcijas veida ietekme uz pēcoperācijas komplikāciju

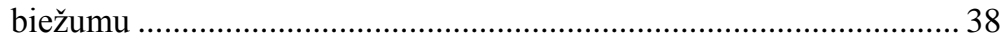

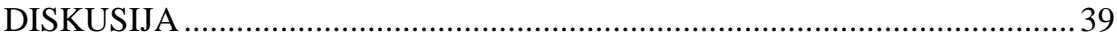

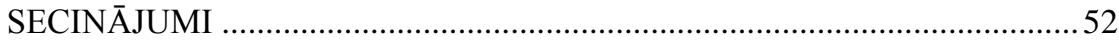

PUBLIKĀCIJAS UN ZIN̦OJUMI PAR PĒTİJUMA TĒMU ............................53

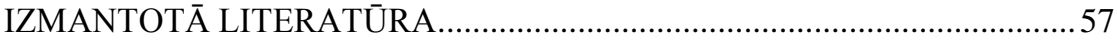

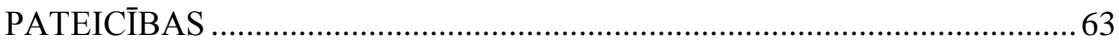




\section{IEVADS}

Galvas kakla vēzis ir bieži sastopams epiteliāls audzējs, kas lokalizējas mutes dobumā, paranazālos sīnusos, deguna dobumā, rīklē un balsenē. Katru gadu pasaulē tiek diagnosticēti 644000 jauni galvas kakla vēža gadījumi, no kuriem divas trešdaļas tiek diagnosticētas jaunattīstības valstīs. Vidējais vecums, kurā pacientam tiek diagnosticēts galvas kakla vēzis ir 60 gadi. Vīriešiem š̄̄ saslimšana tiek diagnosticēta trīs reizes biežāk nekā sievietēm (Jemal 2011).

Mūsu pētījuma galvenais objekts ir pacienti ar ielaistu mutes vēzi, t.i., III un IV stadijas audzēji, kuru ārstēšana ir grūtākā un rezultāti ar ierastajām metodēm nevienozīmīgi. Izvēlējāmies tikai lokāli izplatījušos audzēju gadījumus, kuru radikāla izṇemšana rada plašus audu defektus. Labvēlīgu onkologiisku, funkcionālu un estētisku rezultātu sasniegšanai nepieciešama liela izmēra un komplicētas uzbūves labi apasiņotu audu fragmentu pārstādīšana. Cerīgas iespējas šajā virzienā atklāj mikroķirurğiska labi apasiņotu lielu lēveru transplantācija.

Mutes vēža ārstēšanas metožu izvēelē un ārstēšanas rezultātos izšķiroša nozīme ir vēža izplatības plašumam un dziḷumam attiecīgajā lokalizācijā, vai vērojama izplatība uz blakus rajoniem, izsēšanās pa limfātisko vai asinscirkulācijas sistēmu. Izejot no šiem kritērijiem nosaka audzēja stadijas, izmantojot TNM sistēmu: T - primārā audzēja izmēri, N - izplatība reǵionālajos limfmezglos un $\mathrm{M}$ - hematogēnas metastāzes attālos orgānos.

Vēlīnas III, IV stadijas mutes vēzis raksturojas ar lielu audzēju (T3 un T4) vai/un metastāzēm reǵionālajos limfmezglos (N1, N2, N3). Robežšķirtne starp agrīnu, savlaicīgi diagnosticētu mutes vēzi ir T2 (audzējs ir lielāks kā $2 \mathrm{~cm}$, bet nepārsniedz $4 \mathrm{~cm}$ ) un N0 (kakla limfmezglos metastāzes nav). Papildus galvenajiem etioloǵiskajiem faktoriem, t.i., smēķēšanai un alkoholam, kas visvairāk traucē normālai mutes dobuma epitēlija reǵenerācijai, pēdējā laikā tiek 
vairāk ziṇots par zobārstnieciskās palīdzības iztrūkumu vai nepilnību. Tika novērots, ka mutes vēža slimniekiem, kas bija jaunāki par 64 gadiem, 37\% gadījumu bija bezzobu žokḷi un zobārstu viṇi bija reti apmeklējuši (Rubright, Hoffman et al. 1996).

Latvijā onkoloǵisko saslimšanu biežums pēdējo 10 gadu laikā ir ievērojami pieaudzis. Slimību profilakses un kontroles centra (SPKC) dati rāda, ka 2006. gadā no jauna reǵistrēto onkologiisko saslimšanu gadījumu skaits bija 477,5 pacienti uz 100000 iedzīvotājiem, taču 2016. gadā jau 567,5 pacienti uz 100000 iedzīvotājiem. Šie dati norāda uz $16 \%$ pieaugumu 10 gadu laikā. Saskaṇā ar SPKC 12.06.2017. atjauninātiem pacientu reǵistra datiem, Latvijā 2016. gadā 200 pacientiem tika diagnosticēts lūpas, mutes dobuma, rīkles mutes daļas l̦aundabīgs audzējs (C00-C10, atbilstoši SKK-10 klasifikatoram), kas ir 10,2 pacienti uz 100000 iedzīvotājiem. Savukārt 2009. gadā tie bija 6,92 pacienti uz 100000 iedzīvotājiem. Jāatzīmēe, ka 132 no 200 pacientiem, kuriem diagnosticēts ḷaundabīgs audzējs 2016. gadā, tas tika diagnosticēts vēlīnā stadijā (III stadijā - 45 pacientiem, bet IV stadijā - 87 pacientiem). 21 pacientam mutes vēzis bija diagnosticēts bez stadijas precizējuma. 2009. gadā 86 no 118 pacientiem mutes vēzis tika diagnosticēts vēlīnā stadijā (III stadijā 21 pacientam, bet 65 pacientiem IV stadijā). Analizējot vecuma grupas, 2009. gadā mutes vēža augstākā incidence sievietēm bija 70-74 gadu vecumā, bet 2016. gadā vecuma grupā no 55 līdz 59 gadiem. Savukārt vīriešiem visaugstākā incidence gan 2009. gadā, gan 2016. gadā bija vecuma grupā no 60 līdz 64 gadiem un tikai nedaudz zemāka incidence bija 50-54 gadu vecumā. 2016. gada beigās ar diagnozēm C00-C10 Latvijā onkoloǵisko pacientu reǵistra uzskaitē bija 873 pacienti uz 100000 iedzīvotājiem, no tiem ilgāk par pieciem gadiem pēc diagnozes uzstādīšanas izdzīvoja 472 pacienti.

Pēdējo gadu laikā pasaulē pacientu ar mutes vēzi vidējā dzīvildze ir ievērojami uzlabojusies. Ja 1960. gadā 5 gadu dzīvildze sastādīja 48\%, tad 
2000. gadā 5 gadu dzīvildze sasniedz 63\% (Montero and Patel 2015). Lai arī kopējie piecu gadu izdzīvošanas rādītāji mutes dobuma vēzim pēdējos 30-40 gados ir uzlabojušies, tas pamatā ir noticis pateicoties uzlabotai diagnostikai un ārstēšanai sākumstadijās diagnosticētiem vēžiem. Diemžēl pacientiem ar mutes vēzi vēlīnās stadijās dzīvildzes radītāji nav tik daudzsološi.

Pasaulē 5 gadu dzīvildzes dati pacientiem ar mutes vēzi vēlīnās stadijās ir dažādi, kas būtu skaidrojams ar veselības aprūpes pieejamību, sabiedrības izglīitības līmeni un labklājību noteiktajā reǵionā. Schneider et al. savā pētījumā, analizējot Brazīlijā ārstēto pacientu 5 gadu dzīvildzi, konstatēja, ka pacientiem ar vēlīnās stadijas mutes vēzi 5 gadu dzīvildze ir 30,8\% (Schneider, Flores et al. 2014). Savukārt Vašingtonas Universitātē veiktais pētījums rāda, ka ārstēto pacientu ar mutes vēzi 5 gadu dzīvildze ir 57\% (Sessions, Spector et al. 2002). Slimības apkopojošos rakstos 5 gadu dzīvildze ārstētiem pacientiem ar mutes vēzi vidēji ir 50\% (Kumar, Nanavati et al. 2016), taču šis rādītājs ir sasniegts tikai dažās publikācijās. Pētot sīkāk vēlīno stadiju mutes audzēju ārstēšanas rezultātus, redzams, ka aina nav tik optimistiska, un rezultāti var krasi atšķirties. Ārstēto pacientu ar mutes vēzi atšķirīgā dzīvildze ir saistīta ar pieejamo ārstēšanas metožu dažādību un iespējām tās kombinēt dažādās valstīs. Pablo $H$. Montero un Snehal G. Patel apkopoja literatūrā pieejamos dzīvildzes rādītājus dažādās pasaules valstīs, skatît 1. tabulu (Montero and Patel 2015).

1. tabula

\section{Ar mutes vēzi ārstēto pacientu 5 gadu dzīvildzes apkopojums dažādās pasaules valstīs}

\begin{tabular}{|l|c|c|c|c|c|c|c|}
\hline Valsts & Gads & $\begin{array}{c}5 \text { gadu } \\
\text { Pacientu } \\
\text { skaits } \\
\text { visu } \\
\text { stadiju } \\
\text { pacientiem } \\
(\%)\end{array}$ & $\begin{array}{c}\text { I } \\
\text { stadija } \\
(\%)\end{array}$ & $\begin{array}{c}\text { II } \\
\text { stadija } \\
(\%)\end{array}$ & $\begin{array}{c}\text { III } \\
\text { stadija } \\
(\%)\end{array}$ & $\begin{array}{c}\text { IV } \\
\text { stadija } \\
(\%)\end{array}$ \\
\hline ASV & 1997. & 398 & 57 & - & - & - & - \\
\hline
\end{tabular}


1. tabulas turpinājums

\begin{tabular}{|l|c|c|c|c|c|c|c|}
\hline Valsts & Gads & $\begin{array}{c}\text { Pacientu } \\
\text { skaits }\end{array}$ & $\begin{array}{c}\text { dzadu } \\
\text { dzivildze } \\
\text { visu } \\
\text { stadiju } \\
\text { pacientiem } \\
(\%)\end{array}$ & $\begin{array}{c}\text { I } \\
\text { stadija } \\
(\%)\end{array}$ & $\begin{array}{c}\text { II } \\
\text { stadija } \\
(\%)\end{array}$ & $\begin{array}{c}\text { III } \\
\text { stadija } \\
(\%)\end{array}$ & $\begin{array}{c}\text { IV } \\
\text { stadija } \\
(\%)\end{array}$ \\
\hline Taivāna & 1999. & 7032 & 36,1 & 72,0 & 38,9 & 26,7 & 11,8 \\
\hline ASV & 2000. & 30803 & 43 & - & - & - & - \\
\hline Brazīija & 2002. & 3642 & 43 & \multicolumn{2}{|c|}{74} & \multicolumn{2}{|c|}{33,0} \\
\hline Indija & 2000. & 15051 & 45,9 & \multicolumn{2}{|c|}{68,9} & 26,6 & 9,5 \\
\hline Anglija & 2008. & 541 & 56 & - & - & - & - \\
\hline ASV & 2014. & 1816 & 62 & 78,5 & 68,4 & 64,5 & 34,5 \\
\hline
\end{tabular}

Diemžēl arī pasaulē $60 \%$ gadījumu mutes vēzis tiek diagnosticēts un ārstēšana uzsākta III un IV stadijā ar 5 gadu dzīvildzi 10-40\% (Gorsky and Dayan 1995, Onizawa, Nishihara et al. 2003, Brouha, Tromp et al. 2005, Morelatto, Herrera et al. 2007, Huang and O'Sullivan 2013).

Šobrīd Latvijā nav pieejama precīza mutes vēža slimības stadiju 5 gadu dzīvildzes statistika.

Neārstējot pacientus ar mutes vēzi, vēlīnās stadijās 5 gadu dzīvildze ir tikai 12,6\% (Cheraghlou, Kuo et al. 2018).

Dzīves kvalitāte ir jēdziens, kas sevī ietver gan objektīvus, gan subjektīvus indikatorus, un to savstarpējās mijiedarbības kopumu, kas atspoguļojas noteiktā labklājības pakāpē, kura ir atkarīga no indivīda resursiem un zināšanām. Cilvēkam ar funkcionāliem traucējumiem dzīves kvalitāte nozīmē, ka ir apmierinātas indivīda pamatvajadzības un indivīdam ir iespējas īstenot pamata funkcijas sabiedrībā (izglìtība, darbs, gimene un sociālās attiecības). Šajā pētījumā tika analizētas ielaistu, vēlīnu stadiju onkoloǵisku slimnieku radikālas ķirurğiskas ārstēšanas iespējas, izvērtējot mikroķirurǵiskās rekonstrukcijas medicīniskos rezultātus. Apzinoties dzīves kvalitātes nozīmi onkologisko pacientu dzīvē, veicām arī šì aspekta subjektīvu novērtēšanu, ņemot vērā personīgos un sabiedriskās dzīves faktorus. 


\section{Darba mērḳis}

Pierādīt, ka mutes dobuma vēža vēlīnās (III-IV) stadijās viena etapa audzēja ekscīzija un defekta rekonstrukcija ar mikrovaskulāru lēveri dod iespēju radikāli ārstēt pacientus ar mutes vēzi vēlīnās stadijās, pagarina pacientu dzīvildzi un uzlabo dzīves kvalitāti.

\section{Darba uzdevumi}

1. Salīdzināt 2 gadu dz̄̄vildzi pacientiem, kuriem pielietota viena etapa ķirurğiska ārstēšana, ar pacientiem, kuriem pielietota staru terapija kā primārā vēlīnu stadiju mutes vēža ārstēšanas metode.

2. Salīdzināt 5 gadu dzīvildzi pacientiem, kuriem veikta viena etapa vēlīnu stadiju mutes vēža ekscīzija un mutes dobuma rekonstrukcija ar mikrovaskulāru lēveri, ar pacientiem, kuriem pielietota staru terapija, kā primārā ārstēšanas metode.

3. Analizēt dažādu faktoru ietekmi uz dzīvildzi pacientiem ar vēlīnu stadiju mutes vēzi.

4. Veikt agrīna pēcoperācijas perioda un komplikāciju analīzi pacientu grupai ar mīksto audu rekonstrukciju un pacientiem ar kompleksu mīksto un kaulaudu rekonstrukciju.

5. Noteikt un salīdzināt ķirurgíski ārstēto pacientu dzīves kvalitāti pirms ārstēšanas, 3 mēnešus pēc ārstēšanas un 12 mēnešus pēc ārstēšanas. 


\section{Darbā izvirzītās hipotēzes}

Mutes vēža vēlīnās stadijās viena etapa audzēja ekscīzija un defekta rekonstrukcija ar mikrovaskulāru lēveri dod iespēju veikt radikālu audzēja ārstēšanu.

Mikrovaskulāro rekonstrukciju agrīnās komplikācijas ir atkarīgas no audzēja stadijas, pacientu vecuma, blakusslimībām, un pielietotās rekonstrukcijas metodes.

Pacientu dzīves kvalitātes rādītāji, veicot mutes dobuma rekonstrukciju ar mikrovaskulāru lēveri tiek saglabāti vai pat uzlaboti salīdzinot ar pirms ārstēšanas dzīves kvalitātes rādītājiem.

Mutes vēža pacientu dzīvildze un dzīves kvalitāte ir atkarīga no audzēja lokalizācijas un izvēlētās mutes dobuma rekonstrukcijas metodes. 


\section{MATERIĀLS UN METODES}

\subsection{Pacientu grupas un atlase}

Pētījumā tika iekḷauti 185 pacienti, kuriem klīniski diagnosticēts un histologiski apstiprināts mutes vēzis vēlīnā stadijā. Visiem pacientiem tika veikta biosija ar kuras palīdzību verificēja audzēja morfolog̣iju. Pacienti tika sadalīti divās grupās. Pirmajā grupā tika iekḷauti 142 pacienti, kuriem tika pielietota ķirurğiska ārstēšana. Visi pacienti tika operēti Rīgas Austrumu slimnīcā, Latvijas Onkologijas centrā no 2008. gada novembra līdz 2016. gada aprīlim. Visiem pētījumā iekḷautajiem 142 pacientiem tika histoloğiski verificēts audzējs, izvērtēts limfmezglu stāvoklis, un izslēgtas attālas metastāzes. Izejot no audzēja lokalizācijas un apkārtējo struktūru iesaistes, tika veikta audzēja ekscīzija. Pacientiem, kam bija tikai mīksto audu audzējs bez ieaugšanas kaulaudos, tika veikta tikai mīksto audu rezekcija. Gadījumos, kad audzējs ieaudzis apakšžoklī vai augšžoklī, tad tika veikta arī kaula rezekcija (segmetāla mandibulektomija, vai maksilloektomija). Pacientiem tika izvērtēti kakla limfmezgli, veicot USG, vai gadījumos, kad bija indicēts, tika veikta CT vai MRI. Pacientiem, kam pastāvēja aizdomas vai bija diagnosticēta specifiska limfadenopātija, tika veikta selektīva iesaistīto vai aizdomīgo limfmezglu limfoadenektomija. Lai ievērotu antiseptikas un aseptikas pamatprincipus, pacientiem ar mutes vēzi un specifisku limfoadenopātiju kaklā, vispirms tika veikta selektīva limfadenektomija, un tad tika ekscidēts audzējs. Tādējādi tika samazināts risks brūces infekcijai. Pēc audzēja ekscīzijas, vai gadījumos, kad defekta izmērs bija prognozējams, audzēja ekstripācijas laikā, tika uzsākta lēvera elevācija. Pacientiem, kuriem bija nepieciešama mīksto audu rekonstrukcija visbiežāk tika pārstādīti fasciokutāni lēveri. Biežāk lietotie lēveri bija radiālās artērijas lēveris (RAL), laterālais augšdelma lēveris (LAL) vai priekšējais laterālais augšstilba lēveris 
(ALT - anteriorlateral thigh flap). Pacientiem, kam nepieciešama apakšžokḷa vai augšžokḷa segmenta vai totāla rekonstrukcija, tika pārstādīts osteokutāns lēveris, vai himēras tipa lēveris. Osteokutāns lēveris sevī iekḷauj apasingotu kaula transplantātu un apasiņotu ādas-fascijas lēveri. Savukārt himēras tipa lēveris, var būt no dažādiem asinrites baseiniem veidots lēveris, kas sevī ietver apasiņotu kaulu, muskuli, fasciju, cīpslu un ādu. Lēvera dizains tiek pielāgots attiecībā, kādas mutes dobuma struktūras nepieciešams rekonstruēt. Izvērtējot gala histologijas atbildi, pēc operācijas pacientiem, kuriem bija indicēta, tika nozīmēta staru terapija, un, ja nepieciešams, arī ķīmijterapija. Indikācijas izvērtēja staru un ķīmijterapeitu konsīlijs. Ķīmijterapijas pielietošana tika saskaņota arī ar Nacionālo veselības dienestu.

Kā kontrolgrupa tika izmantota pacientu grupa, kuri nepiekrita ķirurǵiskai ārstēšanai, un kā pamatārstēšanas metode tika veikta staru terapija, atsevišķos gadījumos, kuros tas bija nepieciešams, pievienojot ķīmijterapiju. Kontrolgrupā tika iekḷauti 43 pacienti. Visiem kontroles grupas pacientiem tika veikta biopsija, lai verificētu audzēja morfolog̣iju. Kontrolgrupas pacienti saņēma staru terapiju ar vai bez papildus ķ̄imijterapijas. Ārstēšanas plāns tika apstiprināts onkologu konsīlijā Rīgas Austrumu klīniskās universitātes slimnīcas stacionārā "Latvijas Onkologijas centrs”. Konsīlijā piedalījās otorinolaringologs, sejas žokḷu ķirurgs, staru terapeits, ķīmijterapeits un plastikas ķirurgs. Ķīmijterapijas pielietošana tika saskaņota arī ar Nacionālo veselības dienestu (NVD). Pētījums tika veikts no 2008. gada 2. decembra līdz 2018. gada 18. februārim.

\subsubsection{Iekḷaušanas kritēriji}

Pētījumā tika iekḷauti pacienti, kuriem:

- $\quad$ klīniski diagnosticēts un histologiski verificēts mutes vēzis vēlīnā (III-IV) stadijā; 
- nav diagnosticētas attālas metastāzes;

- pacients piekrīt piedalīties pētījumā.

\subsubsection{Izslēgšanas kritēriji}

Pētījumā netika iekḷauti pacienti, kuriem:

- diagnosticētas attālas metastāzes;

- pacienta vispārējais veselības stāvoklis neḷauj veikt ķirurğisku ārstēšanu;

- audzējs ir inoperabls.

\subsection{Pētījuma metodes}

Pētījuma metodes var iedalīt divos virzienos. Pirmais pētījuma virziens ir analizēt audzēja patomorfoloǵisko raksturojumu, audzēja lokalizāciju, tā stadiju, pielietoto ārstēšanu, rekonstrukcijas metodi, ārstēšanas rezultātu un pacienta dzīvildzi. Pacientu atlases kritēriji paskaidroti 1.1. attēlā.

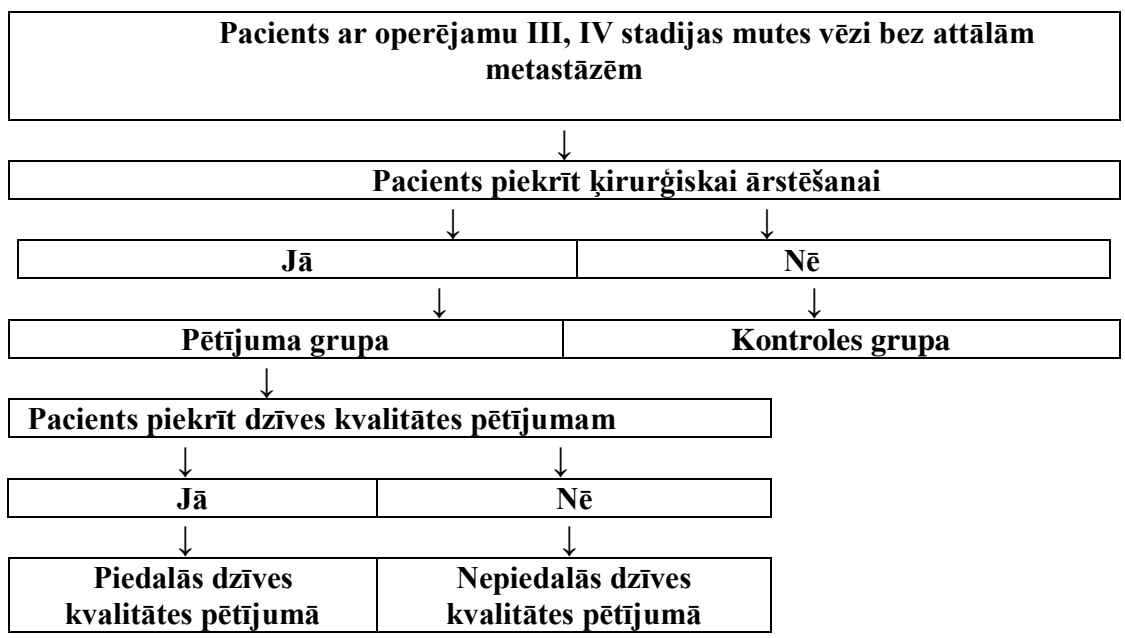

1.1. attēls. Pacientu atlases kritēriji pētījuma grupai, kontroles grupai un dzìves kvalitātes pētijuma grupai 


\subsubsection{Dzīvildzes novērtēšanas metodika}

Pētījuma grupā iekḷautajiem pacientiem tika veikta tumora ekscīzija, ar vai bez kakla limfadenekomijas, un tika veikta mutes dobuma rekonstrukcija ar mikrovaskulāru lēveri. Pacienti tika novēroti no 5 dienām līdz 3103 dienām, vidējais novērošanas laiks 860 dienas.

Lai izvērtētu pacienta vispārējo un lokālo stāvokli, rekonstruētās daḷas funkciju un estētisko rezultātu pacienti ieradās uz vizīti pie ārsta 3 mēnešus, 6 mēnešus un 12 mēnešus pēc operācijas. Tālākā apsekošana tika veikta attiecīgi 18 mēnešus, 24 mēnešus pēc operācijas. Apskates laikā tika izvērtēts pacienta vispārējais veselības stāvoklis. Tika apsekots lokālais stāvoklis, lai izslēgtu lokālu recidīva esamību. Pētījumā iekḷauto pacientu klīniskie dati tika analizēti, izvērtējot audzēja topogrāfiju, patomorfologisko raksturojumu, pielietoto ārstēšanu, rekonstrukcijas metodi un ārstēšanas rezultātu. Lai varētu salīdzināt ķirugiiskas ārstēšanas rezultātus, tika izveidota un pētīta kontroles grupa. Kontroles grupā tieka iekḷauti pacienti ar mutes vēzi vēlīnā stadijā, kuriem netika pielietota ķirurǵiska ārstēšana. Kontroles grupas pacienti, kā pamata ārstēšanas metodi, saņēma staru terapiju ar vai bez papildus ķīmijterapijas. Kontroles grupā iekļauto pacientu klīniskie dati tika analizēti, izvērtējot audzēja topogrāfiju, patomorfoloǵisko raksturojumu, pielietoto ārstēšanu, ārstēšanas rezultātu un dzīvildzi.

\subsubsection{Dzīves kvalitātes novērtēšanas metodika}

Lai izvērtētu mutes dobuma rekonstrukcijas rezultātu, tika izmantotas divu veidu izvērtēšanas metodes. Viena ir objektīva - klīnicista veikta izmeklēšana, otra ir pacienta paša novērtējums. Funkcionālus rezultātus tādus kāa 
rīšana, mutes oklūzija (slēgšanās), mutes atvērums, lūzuma konsolidācija tika novērtēta, veicot klīniskus vai radiologiiskus testus, savukārt subjektīvos, piemēram, estētiskos rezultātus izvērtēja pats pacients. Šos abus raksturlielumus apvieno izstrādātā dzīves kvalitātes novērtējuma anketa. Mūsu pētījumā, lai izvērtētu pētījuma grupas pacienta dzīves kvalitāti (DZK) pēc operācijas, tika izmantota Vašingtonas Universitātes dzīves kvalitātes anketa (University of Washington Quality of Life Questionnaire (UW-QOL v4)), kas l̦auj sistematizēt un pacientam subjektīvi izvērtēt savu dzīves kvalitāti, kam ir samērā tieša korelācija ar pacientam veiktās rekonstrukcijas rezultāta novērtējumu. Pacientiem, kuri piekrita piedalīties DZK pētījumā bija jāaizpilda University of Washington Quality of Life Questionnaire version 4 (UW-QOL v4) anketu pirms operācijas, 3 mēnešus pēc operācijas un 12 mēnešus pēc operācijas. Diemžēl tikai 20 pacienti pētījumu pabeidza. Pacienta nāve, nepiln̄̄gi aizpildīta anketa, vai neierašanās uz kontrollaika nozīmēto aptaujas vizīti, bija iemesli kāpēc pacienti tika izslēgti no dz̄ives kvalitātes pētījuma.

UW-QOL v4 sastāv no divām jautājumu grupām. Pirmo grupu veido trīs tā sauktie globālo jautājumu domēni, katram domēnam ir 5-6 atbilžu varianti, kas tiek novērtēti no 0 (vissliktākais) līdz 100 (vislabākais) punktiem (1.1. tabula). Otro jautājumu grupu veido ar slimību saistîto jautājumu domēni. Tādi ir 12 jautājumu domēni, kuriem ir 3 līdz 6 atbilžu varianti, kas tiek novērtēti no 0 (vissliktākais) līdz 100 (vislabākais) punktiem atbilstošā kārtībā (1.2. tabula).

1.1. tabula

\section{Dzīves kvalitātes novērtēšanas globālo jautājumu domēni}

\begin{tabular}{|cc|}
\hline $\begin{array}{c}\text { Kā Jūs vērtētu savu ar veselības stāvokli saistīto dzīves kvalitāti mēnesi pirms Jums } \\
\text { attīstījās vēzis? }\end{array}$ \\
\hline Daudz labāk & 100 \\
\hline Mazliet labāk & 75 \\
\hline Apmēram tāpat & 50 \\
\hline
\end{tabular}


1.1. tabulas turpinājums

\begin{tabular}{|c|c|}
\hline Nedaudz sliktāk & 25 \\
\hline Daudz sliktāk & 10 \\
\hline \multicolumn{2}{|c|}{$\begin{array}{l}\text { Vispārīgi Jūs teiktu, ka ar Jūsu veselības stāvokli saistîtā dzīves kvalitāte pēdējās } \\
7 \text { dienās ir: }\end{array}$} \\
\hline Izcila & 100 \\
\hline Loti laba & 80 \\
\hline Laba & 60 \\
\hline Mērena & 40 \\
\hline Zema & 20 \\
\hline L̦oti zema & 0 \\
\hline \multicolumn{2}{|c|}{$\begin{array}{l}\text { Tā kā dzīves kvalitāte ir ne tikai fiziska un garīga veselība, bet ieklaaj sevī arī } \\
\text { daudzus citus faktorus, kā gimene, draugi, garīgums, personīgie valasprieki, kas ir } \\
\text { svarīgi dzīvespriekam. Nemot vērā visu, kas sniedz personīgu labklājību, novērtējiet } \\
\text { savu dzīves kvalitāti pēdējās } 7 \text { dienās. }\end{array}$} \\
\hline Izcila & 100 \\
\hline Loti laba & 80 \\
\hline Laba & 60 \\
\hline Mērena & 40 \\
\hline Zema & 20 \\
\hline Loti zema & 0 \\
\hline
\end{tabular}

\section{Ar slimību saistīto jautājumu domēni (jautājumi par pēdējām 7 dienām)}

\begin{tabular}{|l|}
\hline \multicolumn{1}{|c|}{ Sāpes } \\
\hline Nav sāpes (100) \\
\hline Nelielas sāpes nevajag medikamentus (75) \\
\hline Vidējas sāpes lietoju regulāri medikamentus (50) \\
\hline Stipras sāpēs lietoju recepšu medikamentus (25) \\
\hline Stipras sāpes, kuras nevar kontrolēt ar medikamentiem (0) \\
\hline Izskats \\
\hline Nav izmainuu izskatā (100) \\
\hline Nelielas izmaiṇas izskatā (75) \\
\hline Mans izskats man nepatīk, bet es sadz̄ivoju ar to (50) \\
\hline Mans izskats man traucē atrasties publiskās vietās (25) \\
\hline Es nevaru atrasties cilvēkos sava izskata dēḷ (0) \\
\hline Aktivitāte \\
\hline Esmu aktīvs, kā agrāk (100) \\
\hline Ir reizes kad es nevaru būt tikpat aktīvs, bet ne bieži (75) \\
\hline
\end{tabular}




\begin{tabular}{|c|}
\hline Esmu noguris un samazinājis savas aktivitātes, tomēr kustos (50) \\
\hline Es ārā neeju, jo nav spēka (25) \\
\hline Pārsvarā es guḷu vai sēžu un ārā neeju (0) \\
\hline Atpūta \\
\hline Nav problēmu atpūsties mājās vai ārpus tās (100) \\
\hline Ir dažas lietas ko nedaru vairāk, bet joprojām baudu dzīvi (75) \\
\hline Bieži vēlos doties ārpus mājas, bet pietrūkst spēka (50) \\
\hline Ir daudz ierobežojumi, ko es nevaru darīt, tāpēc palieku mājās un skatos TV (0) \\
\hline 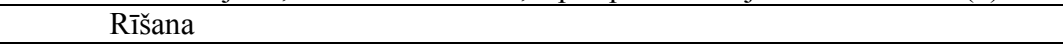 \\
\hline Es varu norìt kā iepriekš (100) \\
\hline Es nevaru norīt noteiktu cietas barības veidu (70) \\
\hline Varu norìt tikai šķidru barību (30) \\
\hline Es nevaru norìt, jo aizrijos $(0)$ \\
\hline Košļāšana \\
\hline Varu koșșāt kā iepriekš (100) \\
\hline Varu ēst gandrīz jebkuru cietu barību (50) \\
\hline Nevaru košl̦āt cietu barību (0) \\
\hline Runa \\
\hline Mana runa nav mainījusies (100) \\
\hline Man ir problēmas izrunāt atsevišķus vārdus, bet runājot pa tālruni mani saprot (70) \\
\hline Vienīgi ǵimene saprot ko es runāju (30) \\
\hline Manu runu nesaprot $(0)$ \\
\hline Plecs \\
\hline Man nav problēmas ar manu plecu (100) \\
\hline Mans plecs ir stīvs, bet tas neietekmē manu spēku (70) \\
\hline Sāpes plecā ir mainījušas manus dzīves paradumus (30) \\
\hline Es nevaru strādāt pleca dēḷ (0) \\
\hline Garša \\
\hline Varu sajust garšu normāli (100) \\
\hline Garšu sajūtu vairumam èdiena (70) \\
\hline Varu sajust garšu dažiem èdieniem (30) \\
\hline Nejūtu garšu vispār (0) \\
\hline Siekalas \\
\hline Manas siekalas ir normālas konsistences (100) \\
\hline Man ir mazāk siekalu kā parasti, bet ir labi (70) \\
\hline Man ir par maz siekalu (30) \\
\hline Man nav siekalu (0) \\
\hline Garastāvoklis \\
\hline Mans garastāvoklis ir lielisks (100) \\
\hline Mans garastāvoklis ir labs, reizēm to ietekmē vēža saslimšana (75) \\
\hline Esmu ne labā, ne sliktā garastāvoklī saistībā ar vēža saslimšanu (50) \\
\hline
\end{tabular}


1.2. tabulas nobeigums

\begin{tabular}{|l|}
\hline Esmu depresijā, jo esmu slims (0) \\
\hline Raizes \\
\hline Es neraizējos par savu vēža saslimšanu (100) \\
\hline Esmu nedaudz noraizējies par vēža saslimšanu (70) \\
\hline Esmu noraizējies par vēža saslimšanu (30) \\
\hline Esmu ļoti noraizējies par vēža saslimšanu (0) \\
\hline
\end{tabular}

Nobeigumā pacientiem jāatzīmē vissvarīgākās no zemāk uzskaitītajām problēmām pēdējo 7 dienu laikā (līdz 3 problēmām):

Sāpes, izskats, aktivitāte, atpūta, rī̌sana, košşāšana, runa, plecs, garša, siekalas, garastāvoklis, raizes.

Iegūtās anketas tika analizētas, attiecīgi ievērojot UW-QOL v4 vadlīnijas (Head and Neck Surgery Outcome Tool: UW-QOL-R4).

\subsection{Datu statistiskā analīze}

Statistiskā analīze tika veikta pielietojot Microsoft Excel (2016) un IBM SPSS version 24.0 programatūru (SPSS, Inc., Armonk, NY, USA). Rezultāti tika prezentēti kā vidējā vērtība $M$ un ( \pm standarta deviācija). Kategoriskās pazīmes tika izteiktas skaițos un procentos un analizētas izmantojot Pīrsona hī kvadrāta vai Fišera precīzo testu. Korelācijas analīzei izmantoja Spīrmena korelācijas koeficienta analīzi $\left(\mathrm{r}_{\mathrm{s}}\right)$. Izdzīvotības jeb dzīvildzes analīzei izmantoja KaplanaMeijera analīzi ar sekojošu Log-ranka statistiskā testa analīzi, vairāku izdzīvotības līkṇu savstarpējai atšķirību vērtēšanai izmantoja Post-hoc analīzi. Dzīvildzes līknes novērtēšanai izmantoja mediānu (Me) un atbilstošo 95\% ticamības līmeni. P-vērtība 0,05 tika uzskatīta kā statistiski ticama. 


\section{REZULTĀTI}

\subsection{Slimnieku klīniskais un vēža patomorfoloğiskais raksturojums}

Pētījuma grupā, kurā tika veikta ķirurǵiska ārstēšana ar vai bez staru terapijas un ķ̄imijterapijas, tika iekļauti 142 pacienti. Visiem pacientiem pirms ārstēšanas tika veikta diagnostiskā biopsija. Diviem pacientiem tika histologiiski verificēta bazālšūnu karcinoma (1\%), bet 140 pacientiem tika histologiski diagnosticēts plakanšūnu vēzis (99\%). Kontroles grupā, kas saņēma tikai staru terapiju ar vai bez ķīmijterapijas, tika iekḷauti 43 pacienti. Visiem pacientiem pirms ārstēšanas tika veikta diagnostiskā biopsija. Visiem kontroles grupas pacientiem (100\%) tika histoloǵiski verificēts plakanšūnu vēzis (2.1. attēls).

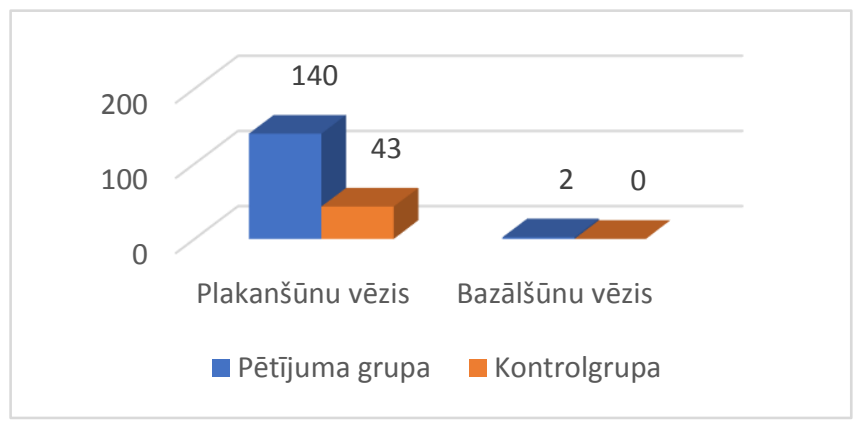

\section{1. attēls. Patomorfologiskais vēžu sadalījums pētījuma un kontroles grupās}

Izvērtējot klīniski primārā tumora izmēru, lokalizāciju un saistību ar apkārtējām audu struktūrām pētījuma grupā T3 stadija tika diagnosticēta 93 pacientiem (65\%), T4 tika diagnosticēta 49 pacientiem (35\%). Izvērtējot klīniski primārā tumora izmēru kontroles grupā T3 tika diagnosticēts 22 pacientiem (51\%) un T4 tika diagnosticēts 21 pacientam (49\%). Skatît 2.2. attēlu. 


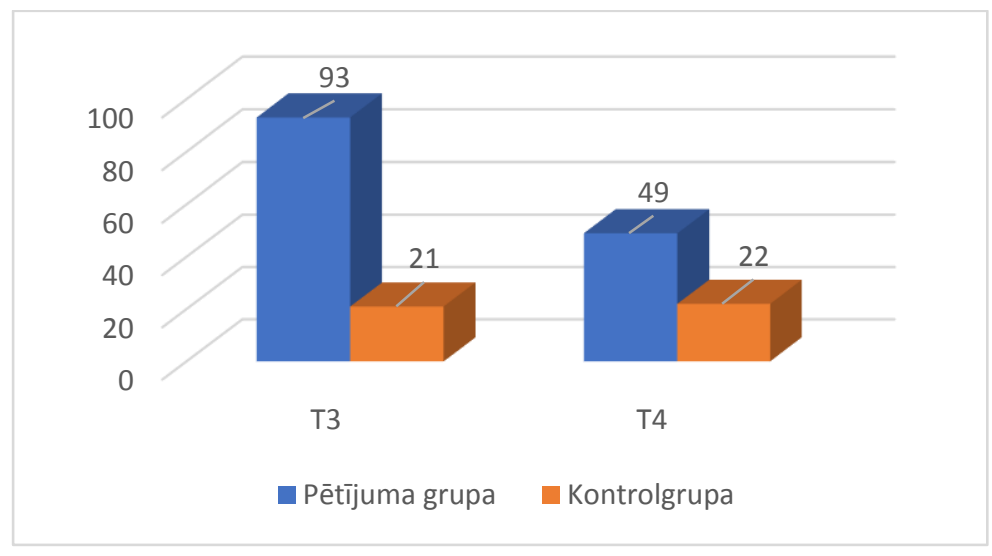

\section{2. attēls. Pacientu sadalījums pēc T pētījuma grupā un kontroles grupā}

Pētījuma grupāa, izvērtējot reǵionālo limfmezglu iesaistes pakāpi un apjomu, 54 pacientiem (38\%) netika diagnosticētas metastāzes kakla limfmezglos (N0), N1 stadija tika konstatēta 45 pacientiem (32\%), N2 stadija tika diagnosticēta 42 pacientiem (29\%), un N3 stadija tika konstatēta vienam pacientam (1\%). Nevienam no pētījuma grupā iekḷautajiem pacientiem netika diagnosticētas attālas metastāzes (M0).

Kontroles grupā, izvērtējot regionālo limfmezglu iesaistes pakāpi un apjomu, metastāzes kakla limfmezglos (N0) netika konstatētas 5 pacientiem (12\%), N1 stadija tika konstatēta 19 pacientiem (44\%), N2 stadija bija 18 pacientiem (40\%), N3 stadija tika diagnosticēta 1 pacientam (2\%). Nevienam no kontrolgrupā iekḷautajiem pacientiem netika diagnosticētas attālas metastāzes (M0). Grafisks pacientu sadalījums pēc N stadijas parādīts 2.3. attēlā. 


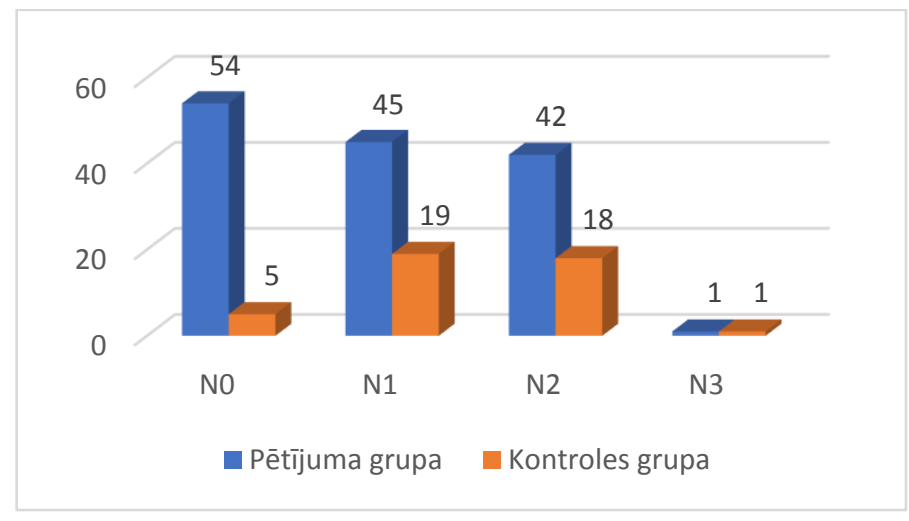

2.3. attēls. Pacientu sadalījums pēc $\mathbf{N}$ pētījuma grupā un kontroles grupā

Pēc gala patomorfologiskās atbildes saņemšanas, izmantojot TNM sistēmas stadiju noteikšanas metodi (staging), pacientiem pētījuma grupā 70 pacientiem tika uzstādīta gala diagnozes stadija III , bet stadija IV tika uzstādīta 72 pacientiem.

Savukārt kontroles grupā stadija III tika uzstādīta 14 pacientiem, bet stadija IV tika uzstādīta 29 pacientiem. Procentuālais pacientu sadalījums pa stadijām pētījuma grupā un kontroles grupā parādīts 2.4. attēlā.

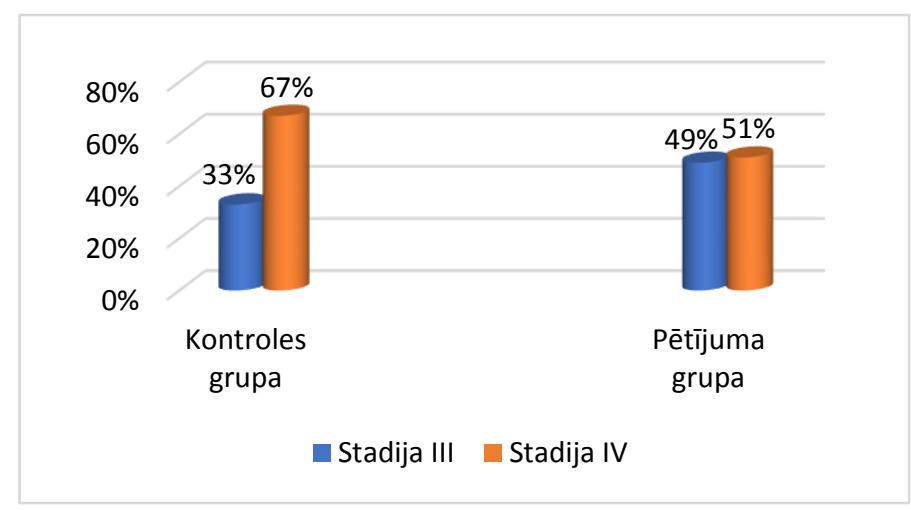

2.4. attēls. Pacientu procentuālais sadalījums pa stadijām kontroles un pētījuma grupās 


\subsection{Dzimums un vecums}

Pētîjuma grupā no 142 pacientiem 31 pacients bija sievietes un 111 pacienti bija vīrieši (2.5. attēls). Vidējais vecums uz ārstēšanas uzsākšanas brīdi bija 58 ( $\mathrm{SD}=11,21)$ gadi (no 30 gadiem līdz 81 gada vecumam). Sieviešu vidējais vecums bija $59(\mathrm{SD}=12,32)$ gadi (no 30 gadiem līdz 81 gadiem). Vīriešu vidējais vecums bija 58 ( $\mathrm{SD}=10,92)$ gadi (no 31 gada līdz 79 gadiem).

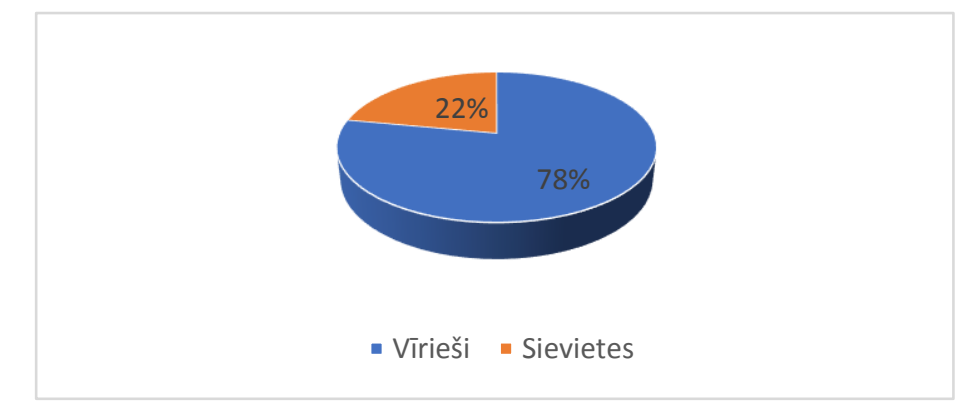

\section{5. attēls. Pētījuma grupas pacientu procentuālais sadalījums pa dzimumiem}

Kontroles grupā no 43 pacientiem 7 bija sievietes, bet 36 pacienti bija vīrieši. Pacientu procentuālais sadalījums pa dzimumiem atspoguḷots 2.6. attēlā. Pacientu vidējais vecums bija $61(\mathrm{SD}=12,35)$ gads (no 27 gadiem līdz 83 gadu vecumam). Vīriešu vidējais vecums bija 59 ( $\mathrm{SD}=12,46$ ) gadi (no 27 gadiem līdz 83 gadiem), savukārt sieviešu vidējais vecums bija $66(\mathrm{SD}=11,08)$ gadi (no 45 gadiem līdz 79 gadiem). 


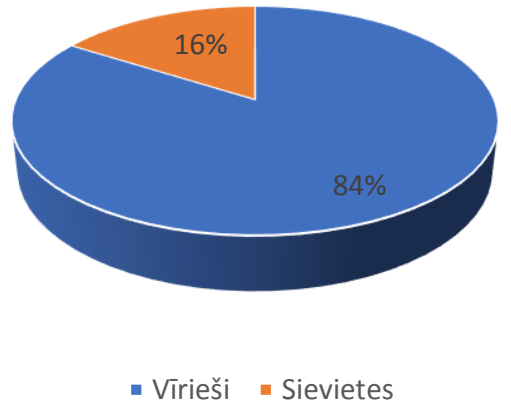

\section{6. attēls. Kontrolgrupas pacientu procentuālais sadalījums pa dzimumiem}

\subsection{Audzēja topogrāfija}

Izvērtējot mutes audzēja lokalizāciju mutes dobumā pētījumu grupā 19 pacientiem audzējs lokalizējās mutes pamatnē, 53 pacientiem audzējs lokalizējās mutes pamatnē ar ieaugšanu mēlē, 20 pacientiem audzēja lokalizācija bija mēle, 6 pacientiem audzējs lokalizējās mutes pamatnē ar ieaugšanu apakšžoklī, 19 pacientiem audzēja lokalizācija bija apakšžoklis, 8 pacientiem audzējs lokalizējās mutes pamatnē ar ieaugšanu vaigā, 7 pacientiem audzējs atradās vaigā, 8 pacientiem audzējs bija no lūpas izejošs, diviem pacientiem audzēja lokalizācija bija augšžoklis.

Izvērtējot mutes audzēja lokalizāciju mutes dobumā kontroles grupā 4 pacientiem audzējs lokalizējās mutes pamatnēe, 12 pacientiem audzējs lokalizējās mēlē, vienam pacientam mutes audzējs lokalizējas vaigā, 6 pacientiem audzējs lokalizējās mutes pamatnē ar ieaugšanu mēlē, vienam pacientam mutes audzējs lokalizējas mutes pamatnē ar ieaugšanu apakšžoklī, 9 pacientiem audzējs lokalizējas mandel̦u lokos (tonsille palatinae) un 
10 pacientiem audzējs lokalizējas mandel̦u lokos ar ieaugšanu mēelē. Audzēja topogrāfijas dati apkopoti 2.1. tabulā.

2.1. tabula

Audzēja topogrāfija pētījuma grupai un kontrolgrupai

\begin{tabular}{|l|c|c|}
\hline \multicolumn{1}{|c|}{ Tumora lokalizācija } & $\begin{array}{c}\text { Reǵionālo limfmezglu } \\
\text { iesaiste pētījuma } \\
\text { grupai N (\%) }\end{array}$ & $\begin{array}{c}\text { Reǵionālo limfmezglu } \\
\text { iesaiste kontroles grupai } \\
\text { N (\%) }\end{array}$ \\
\hline Mutes pamatne & $19(13)$ & $4(9)$ \\
\hline Mēle & $20(14)$ & $12(28)$ \\
\hline Mutes pamatne un mēle & $53(38)$ & $6(14)$ \\
\hline Vaigs & $7(5)$ & $1(2)$ \\
\hline Mutes pamatne un vaigs & $8(6)$ & 0 \\
\hline Apakšžzklis & $19(13)$ & 0 \\
\hline $\begin{array}{l}\text { Mutes pamatne un } \\
\text { apaǩ̌žklis }\end{array}$ & $6(4)$ & $1(2)$ \\
\hline Augšžoklis & $2(1)$ & $0(0)$ \\
\hline Lūpa & $8(6)$ & $9(0)$ \\
\hline Mandel̦u loks & $0(0)$ & $10(24)$ \\
\hline Mandęu loks un mēle & $0(0)$ & \\
\hline
\end{tabular}

\subsection{Klasifikācija pēc TNM sistēmas}

Analizējot pētījuma grupā iekḷauto 142 pacientu gala patomorfoloǵiskos slēdzienus, konstatēja, ka diviem pacientiem tika histoloǵiski verificēta bazālšūnu karcinoma, bet 140 pacientiem tika histoloǵiski diagnosticēts plakanšūnu vēzis. Histologiiski izvērtējot primārā tumora izmēru, T3 tika diagnosticēts 93 pacientiem (65\%), T4 tika diagnosticēts 49 pacientiem (35\%).

Izvērtējot reǵionālo limfmezglu iesaistes pakāpi un apjomu 54 pacientiem netika diagnosticētas metastāzes limfmezglos (N0), N1 stadija tika konstatēta 45 pacientiem, N2 stadija tika diagnosticēta 42 pacientiem, un N3 stadija tika konstatēta vienam pacientam. Salīdzinot pacientu pirms operācijas 
uzstādīto diagnozi, izmantojot TNM audzēja klasifikatoru ar pēcoperācijas gala diagnozi, konstatēja, ka visiem pacientiem uzstādītās diagnozes sakrita.

Nevienam no pētījuma grupā iekḷautajiem pacientiem netika diagnosticētas attālas metastāzes (M0).

Kontroles grupā tika iekl̦auti 43 pacienti, kas saņēma tikai staru terapiju ar vai bez pievienotas ķīmijterapijas. Visiem pacientiem bija histoloǵiski verificēts plakanšūnu vēzis. Izvērtējot primārā tumora izmēru T3 tika diagnosticēts 21 pacientam un T4 tika diagnosticēts 22 pacientiem. Izvērtējot reǵionālo limfmezglu iesaistes pakāpi un apjomu metastāzes kakla limfmezglos netika konstatētas 5 pacientiem (N0), N1 stadija tika konstatēta 19 pacientiem, N2 stadija bija 18 pacientiem, N3 stadija tika diagnosticēta 1 pacientam. Nevienam no kontrolgrupā iekḷautajiem pacientiem netika diagnosticētas attālas metastāzes (M0).

\subsection{Audzēja lokalizācijas saistība ar metastazēšanās biežumu kakla limfmezglos}

Analizējot audzēja lokalizācijas saistību ar audzēja metatstazēšanās tieksmi, audzēju lokalizācijas tika nosacīti sadalītas 3 grupās. Pirmā grupa, kur audzējs ir lokalizēts mutes pamatnē. Otrā grupa, kur audzējs lokalizēts mēlē, trešā grupa audzējs lokalizēts citās mutes dobuma daḷās. Audzēji, kas lokalizējās gan mēlē gan mutes pamatnē tika pieskaitīit pie mēles lokalizācijas, pamatojoties uz to, ka literatūras dati norāda par mēles lokalizācijas audzēju visizteiktāko tieksmi metastazēties kakla limfmezglos.

Apkopojot iegūtos datus, kontroles grupā mutes vēzis lokalizēts mutes pamatnē metastazējās kakla limfmezglos $60 \%$ gadījumu, savukārt pētījuma grupā mutes pamatnes vēzis kakla limfmezglos metastazējās $65 \%$ gadījumu.

Audzēji, kuri bija lokalizēti mēlē kontroles grupā metastazējās 89\% gadījumu, bet pētījuma grupā $68 \%$ gadījumu. 
Audzēji, kas bija nominēti, kā citas lokalizācijas, kontroles grupā kakla metastāzes tika konstatētas 100\%, savukārt pētījuma grupā 30\%. Veicot statistisko analīzi, netika konstatēta statistiski ticama asociācija starp lokalizāciju un N stadiju ( $\mathrm{p}=0,24)$, tomēr ir novērojama tendence, ka mēles lokalizācijai ir visaugstākā metastazēšanās tieksme. Pacientu skaits, kuriem vēzis ir lokalizēts mēlē un ir metastāzes kakla limfmezglos - 2,6 reizes pārsniedz pacientu skaitu, kuriem nav kakla limfmezglos metastāzes, kamēr mutes pamatnei 1,71 reizes, bet citām lokalizācijām - 1,25 reizes pacientu skaits ar metastāzēm kakla limfmezglos pārsniedz pacientus skaitu bez metastāzēm kakla limfmezglos. Audzēja lokalizācijas saistība ar metastazēšanās biežumu pētījumā iekḷautajiem pacientiem ir redzama 2.7. attēlā.

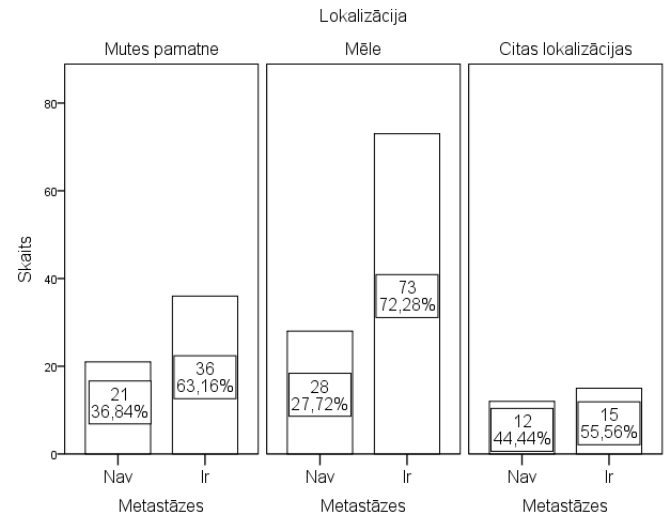

\section{7. attēls. Audzēja lokalizācijas saistība ar metastazēšanās biežumu pētījumā iekḷautajiem pacientiem}

Savukārt audzēja lokalizācijas saistība ar kakla limfmezglu iesaistes pakāpi (N) pētījuma iekḷautajiem pacientiem ir attainota 2.8. attēlā. 


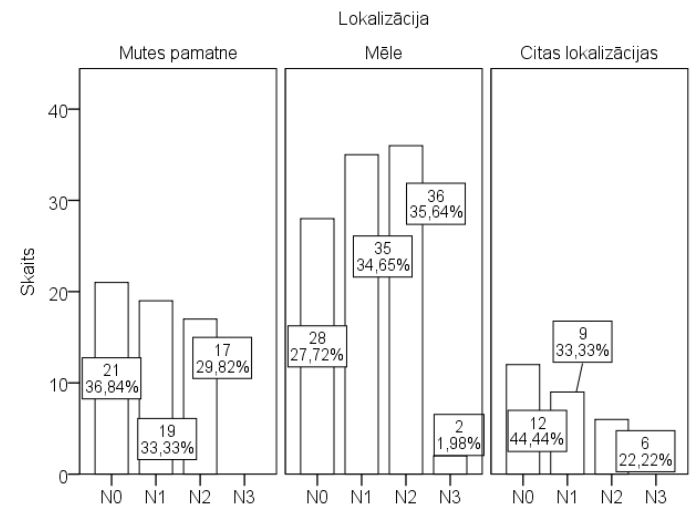

\section{8. attēls. Audzēja lokalizācijas saistība ar N stadiju pētījumā iekḷautajiem pacientiem}

Audzēja lokalizācijas un metastāžu biežuma saistības procentuālais sadalījums pētījuma un kontroles grupās ir redzams 2.9. attēlā.

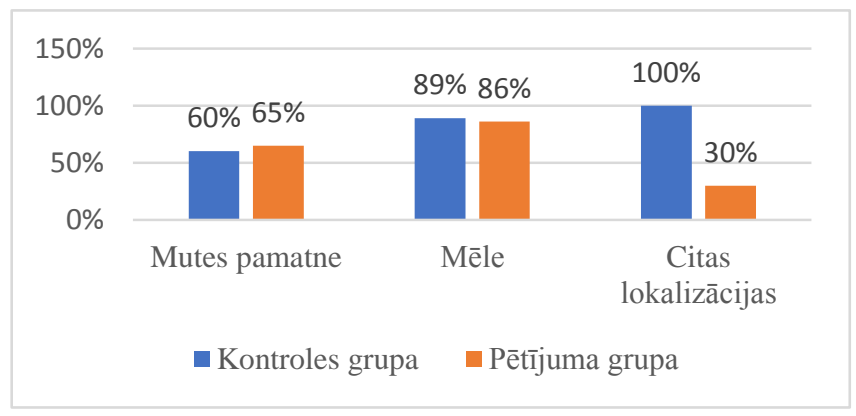

2.9. attēls. Ielaista mutes vēža kakla metastāžu biežums atkarībā no audzēja lokalizācijas kontroles un pētījuma grupās 


\subsection{Blakusslimības}

Analizējot pētījuma grupu, no pêtījuma grupā iekḷautajiem 142 pacientiem blakussaslimšanas netika konstatētas 29 pacientiem. 113 pacientiem tika konstatētas 224 blakussaslimšanas. 40 pacientiem tika konstatēta viena blakussaslimšana, bet 73 pacientiem tika konstatētas divas vai vairākas blakussaslimšanas.

Biežākā konstatētā blakussaslimšana bija smēķētāja bronhīts 80 pacientiem. Otra biežākā saslimšana arteriālā hipertensija - 52 pacientiem. Koronārā sirds slimība tika konstatēta 36 pacientiem. Cukura diabēts 12 pacientiem, centrālās nervu sistēmas (CNS) saslimšanas 11 pacientiem, alkoholisms 9 pacientiem, aknu slimības 6 pacientiem, aterosklerozes diagnoze bija uzstādīta 5 pacientiem, bet kungga čūlas slimība 4 pacientiem, prostatas adenoma un reimatoīdais artrīts 2 pacientiem.

Pieciem pacientiem anamnēzē jau tika diagnosticēts un ārstēts vēl viens citas lokalizācijas audzējs. Audzēji, kuri pacientiem anamnēzē tika ārstēti bija krūts vēzis, plaušu vēzis, dzemdes kakla vēzis, ādas vēzis un ne-Hodžkina limfoma. Brīdī, kad pacienti tika iekḷauti pêtījumā, viṇi tika uzskatīti no šiem audzējiem klīniski veseli.

Analizējot 6 mirušo pacientu datus pētījuma grupā, tika konstatēts, ka visiem sešiem pacientiem bija vairāk kā viena blakusslimība. Četriem pacientiem bija blakussaslimšana arteriāla hipertensija un četriem pacientiem bija smēķētāja bronhīts. Diviem no mirušajiem pacientiem bija koronārā sirds slimība, vienam pacientam bija cukura diabēts, vienam ateroskleroze un vienam alkoholisms. Procentuālais blakussaslimšanu sadalījums mirušo pacientu grupā redzams 2.10. attēlā. 


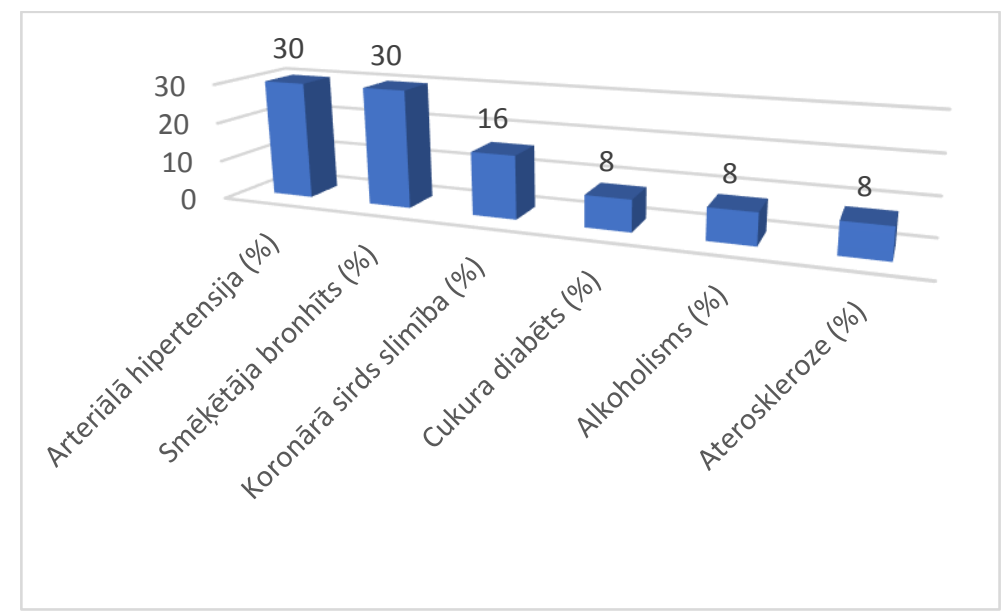

\subsection{0. attēls. Procentuālais blakussaslimšanu sadalījums mirušo pacientu grupā}

Ja analizē pacientu blakusslimības pacientiem, kuriem pētījuma grupā pēc operācijas attīstìjās komplikācijas, tad tika konstatēts, ka no 26 pacientiem, kuriem attīstìjās komplikācijas pēc operācijas, pieciem pacientiem blakusslimības netika diagnosticētas. 6 pacientiem bija viena blakusslimība, bet 19 pacientiem bija vairāk nekā viena blakusslimība. Visbiežāk diagnosticētā blakusslimība bija smēķētāja bronhīts 17 gadījumos, arteriāla hipertensija bija 10 gadījumos, koronāra sirds slimība 8 gadījumos, cukura diabēts un kungéa čūla divos gadījumos. Ateroskleroze, CNS saslimšana, prostatas adenoma un alkoholisms vienā gadījumā.

Analizējot komplikāciju saistību ar blakusslimībām, ieguva, ka no pacientiem, kuriem ir blakusslimības, komplikācijas bija gandrīz piektdaļai $26(18,31 \%)$. Taču $88(61,97 \%)$ pacientiem bija blakusslimības, bet komplikāciju nebija, savukārt $23(16,20 \%)$ pacientiem nebija blakusslimības un nebija arī komplikācijas, bet $5(3,52 \%)$ pacientiem nebija blakusslimības, bet bija komplikācijas (2.11. att.). Statistiski ticama asociācija starp blakusslimībām un 
komplikācijām netika konstatēta $(\mathrm{p}=0,57)$, tomēr aprēķinot izredžu attiecību, ieguva tendenci, ka tiem, kam ir blakusslimības, 1,38 reizes biežāk ir komplikācijas.

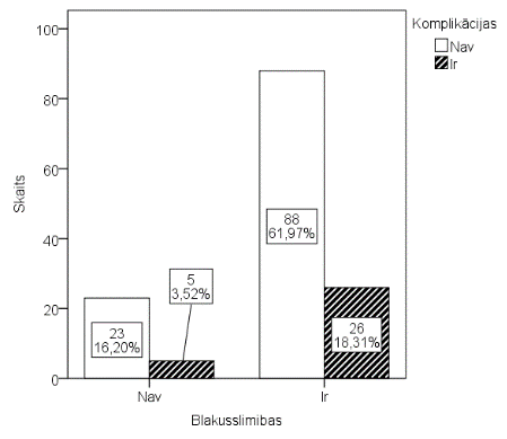

2.11. attēls. Blakusslimību un komplikāciju skaita sadalījums kontroles un pētījuma grupas pacientiem

\subsection{Pacientu dzīvildzes analīze}

Lai noteiktu pacientu izdzīvotību jeb dzīvildzi, tika analizēta pētījuma grupa un kontrolgrupa, izvērtējot pacienta dzimuma, rezekcijas līniju stāvokḷa un audzēja veida, tā stadijas ietekmi uz dzīvildzi. Analizējot gan pētījuma grupā, gan kontroles grupā ārstēto pacientu dzīvildzi, ieguva kopējo izdzīvotības līkni, kas ir parādīta 2.12. attēlā. Visiem kontroles grupā un pētījuma grupā ārstētiem pacientiem izdzīvotības mediāna ir 2,25 gadi (95\% TI: 1,52-2,98 gadi). 


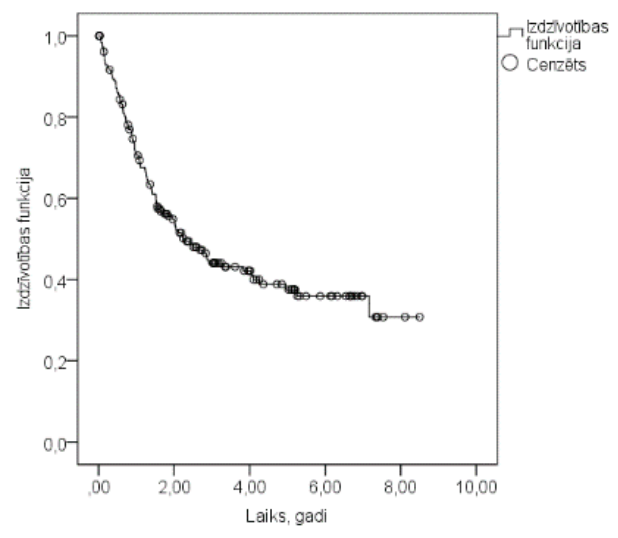

2.12. attēls. Kopējā izdzīvotības līkne

Analizējot kontrolgrupas un pētījuma grupas dzīvildzes rādītājus, tika konstatēts, ka pētījuma grupas dzīvildze ir ievērojami ilgāka, salīdzinot ar kontroles grupu (2.13. att.). Pētījuma grupai 2 gadu dzīvildze bija $60 \%$, bet kontroles grupai 30\%. Savukārt piecu gadu dzīvildze pētījuma grupai bija 42\%, bet no kontroles grupas pacientiem piecus gadus nenodzìvoja neviens pacients.

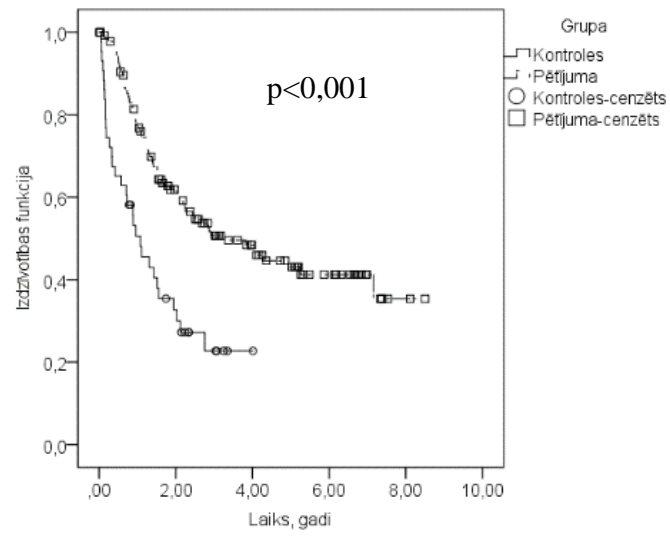

2.13. attēls. Kaplana-Meijera dzivildzes līknes pētījuma grupai un kontroles grupai 
Log-ranka statistiskā testa analīzē konstatēja, ka dzīvildzes līknes kontroles grupai $(\mathrm{Me}=1,07$ gadi; $95 \%$ TI: $0,58-1,57$ gadi) un pētîjuma grupai $(\mathrm{Me}=3,27 ; 95 \% \mathrm{TI}: 1,78-4,76$ gadi) statistiski ticami atšķiras $(\mathrm{p}<0,001)$.

Pētījumā tika analizēta pacientu dzimuma, ekscīzijas līniju, audzēja izmēra ( $\mathrm{T}$ stadijas), limfmezglu iesaistes ( $\mathrm{N}$ stadija) un audzēja diferenciācijas (Grade) ietekme uz pacientu 2 gadu un 5 gadu dzivildzi pētījuma un kontroles grupās.

Faktoru ietekmes kopsavilkums uz 2 gadu un 5 gadu dzīvildzi pacientiem kontroles grupā un pētījuma grupā attēlots 2.2. tabulā.

2.2. tabula

\section{Dažādu faktoru ietekmes kopsavilkums uz 2 gadu un 5 gadu dzīvildzi pacientiem kontroles grupā un pētījuma grupā}

\begin{tabular}{|l|c|c|c|c|}
\hline \multirow{2}{*}{$\begin{array}{c}\text { Ietekmējošie } \\
\text { faktori }\end{array}$} & \multicolumn{2}{|c|}{ 2 gadu dzīvildze } & \multicolumn{2}{c|}{ 5 gadu dzīvildze } \\
\cline { 2 - 5 } & $\begin{array}{c}\text { Kontroles } \\
\text { grupa (\%) }\end{array}$ & $\begin{array}{c}\text { Pētījuma } \\
\text { grupa (\%) }\end{array}$ & $\begin{array}{c}\text { Kontroles } \\
\text { grupa (\%) }\end{array}$ & $\begin{array}{c}\text { Pētījuma } \\
\text { grupa (\%) }\end{array}$ \\
\hline Sievietes & 65 & 65 & 0 & 45 \\
\hline Vīrieši & 25 & 60 & 0 & 42 \\
\hline T3 & 35 & 60 & 0 & 41 \\
\hline T4 & 21 & 60 & 0 & 50 \\
\hline N0 & 58 & 75 & 0 & 65 \\
\hline N1 & 25 & 62 & 0 & 38 \\
\hline N2 & 30 & 40 & 0 & 25 \\
\hline Grade 1 & 25 & 100 & 0 & 100 \\
\hline Grade 2 & 32 & 55 & 0 & 38 \\
\hline Grade 3 & 42 & 61 & 0 & 45 \\
\hline Stage III & 28 & 70 & 0 & 52 \\
\hline Stage IV & 30 & 60 & 0 & 37 \\
\hline Kopējā dzīvildze & & & 0 & 42 \\
\hline
\end{tabular}

\subsection{Dzīves kvalitātes novērtējums}

No pētījumā 142 iekḷautajiem pacientiem dzīves kvalitātes pētījumā piedalīties piekrita 36 pacienti, kam tika veikta mutes vēža ablācija un mutes 
dobuma rekonstrukcija ar mikrovaskulāru lēveri. Pētījumu pabeidza 18 vīrieši (90 \%) un divas sievietes (10\%). Vidējais vecums operācijas laikā bija $53(\mathrm{SD}=10,40)$ gadi (no 34 līdz 76 gadiem).

Izmantojot UW-QOL datu prezentēšanas vadlīnijas (Head and Neck Surgery Outcome Tool: UW-QOL-R4) tika iegūti sekojoši rezultāti globālo jautājumu domēnos. 2.3. tabula atspoguḷo pirms operācijas datus un gadu pēc operācijas datus globālo jautājumus domēnos.

2.3. tabula

\section{UW-QOL globālo jautājumu domēnu rezultāti pirms operācijas un gadu pēc operācijas}

\begin{tabular}{|l|c|c|c|c|}
\hline \multirow{2}{*}{ UW-QOL } & \multicolumn{2}{|c|}{ Pirms operācijas } & \multicolumn{2}{c|}{ Gadu pēc operācijas } \\
\cline { 2 - 5 } & $\begin{array}{c}\text { Vidējā̄ā } \\
\text { vērtība }\end{array}$ & $\begin{array}{c}\text { Labākās } \\
\text { atbildes\% }\end{array}$ & $\begin{array}{c}\text { Vidējā } \\
\text { vērtība }\end{array}$ & $\begin{array}{c}\text { Labākās } \\
\text { atbildes\% }\end{array}$ \\
\hline $\begin{array}{l}\text { A. Salīdzināt ar veselī̄bas } \\
\text { stāvokli saistīto DZK } \\
\text { mēnesi pirms Jums } \\
\text { attīstījās vēzis }\end{array}$ & 14 & 15 & 26 & 25 \\
\hline $\begin{array}{l}\text { B. Jūsu ar veselības } \\
\text { stāvokli saistitā DZK } \\
\text { pēdējās 7 dienās ir }\end{array}$ & 21 & 15 & 64 & 75 \\
\hline $\begin{array}{l}\text { C. Novērtējiet savu DZK } \\
\text { pēdējās 7 dienās }\end{array}$ & 24 & 15 & 58 & 75 \\
\hline
\end{tabular}

Izvērtējot iegūtos datus, ir redzams, ka A domēnā vidējais punktu skaits ir palielinājies no 14 punktiem līdz 26 punktiem, savukārt labāko iespējamo atbilžu procentuālais īpatsvars pieaudzis no 15 līdz 25\%. B domēnā vidējais punktu skaits ir palielinājies no 21 punkta līdz 64 punktiem, bet labāko iespējamo atbilžu procentuālais īpatsvars ir pieaudzis no 15 līdz 75\%. Savukārt C domēnā, vidējais punktu skaits ir pieaudzis no 24 punktiem, līdz 58 punktiem, bet labāko iespējamo atbilžu variantu procentuālais īpatsvars ir palielinājies no $15 \operatorname{lī} \mathrm{dz} 75 \%$. 
Analizējot un izmantojot UW-QOL datu prezentēšanas vadlīnijas iegūtos rezultātus ar slimību saistīto jautājumu domēnos, redzams, ka vidējais punktu skaits pēc operācijas salīdzinot ar pirms operācijas periodu ir palielinājies domēnos - aktivitāte, garastāvoklis, raizes. Statistiski ticami vidējais punktu skaits ir palielinājies domēnā - sāpes $(\mathrm{p}=0,001)$, no 58,75 punktiem līdz 91 punktam. Nav statistiski ticami izmainījies punktu skaits pirms un pēc operācijas pleca $(\mathrm{p}=0,08)$ un siekalu $(\mathrm{p}=0,68)$ domēnos. Punktu skaits samazinājies domēnos - izskats $(\mathrm{p}=0,08)$, atpūta $(\mathrm{p}=0,01)$, rǐšana $(\mathrm{p}=0,1)$, runa $(\mathrm{p}=0,005)$, un garša $(\mathrm{p}<0,001)$. Visizteiktākā pasliktināšanās ir košḷāšanas domēnā $(\mathrm{p}=0,1)$ no 40 puntiem līdz 13 punktiem. Analizējot labāko iespējamo atbilžu variantu, procentuālais īpatsvars ir būtiski pieaudzis sāpju domēnā no 10 līdz 70\%. Vislielākais kritums labāko iespējamo atbilžu procentuālajā īpatsvarā ir garšas domēnā no 80 līdz 25\%. Piln̄̄gi nemainīgs labāko iespējamo atbilžu procentuālais īpatsvars pirms un pēc operācijas saglabājas domēnos plecs $100 \%$ un siekalas $90 \%$.

Izvērtējot DZK iegūtos datus, ieguva, ka bez izmaiņām saglabājas domēni - plecs $(\mathrm{p}=0,08)$ un siekalas $(\mathrm{p}=0,68)$. Statistiski ticams $(\mathrm{p}<0,05)$ uzlabojums ir domēnos - sāpes, garastāvoklis un raizes. Statistiski ticams $(\mathrm{p}<0,05)$ pasliktinājums ir domēnos - košļā̌šana, atpūta, runa un garša. Ar tendenci pasliktināties, bet bez statistiskās ticamības (p > 0,05) bija domēnos - izskats, aktivitāte, rī̌sana. Skatīt 2.14. attēlu. 


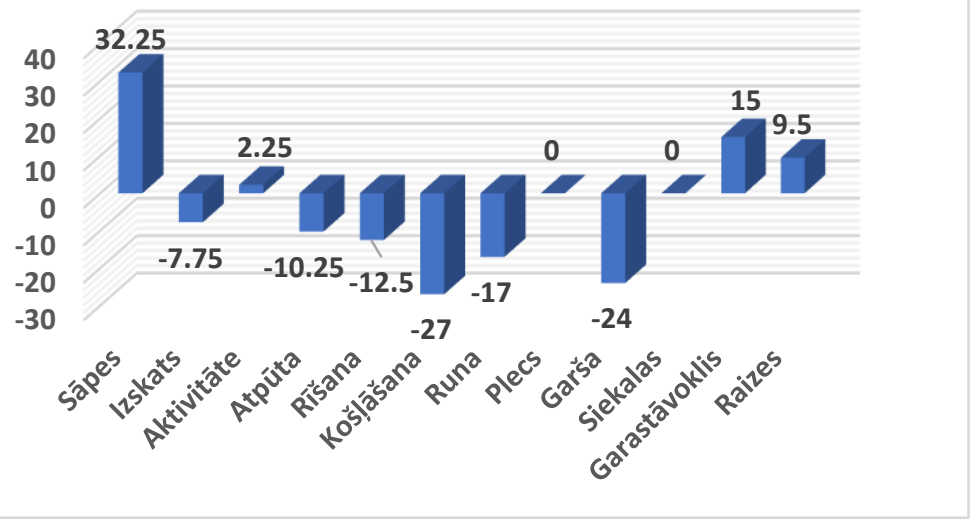

\subsection{4. attēls. Ar slimību saistīto jautājumu domēnu rezultāta izmaiņas gada laikā}

Tāpat pacienti atzīmēja trīs svarīgākās problēmas, ievērojot svarīguma prioritātes. Kā pirmo atzīmējot problēmu, kas pacientu satrauc visvairāk, tad pēc svarīguma otro svarīgāko problēmu un tad trešo svarīgāko problēmu, kas pacientus uztrauc visvairāk trīs laika posmos - pirms operācijas, trīs mēnešus pēc operācijas un gadu pēc operācijas. Vietu sadalījums tika veidots saskaitot sniegtās atbildes un pirmajā vietā ierindojot problēmu, kura satrauc visvairāk vislielāko aptaujāto pacientu skaitu. Analizējot pacientu atbildes, tika iegūta sekojošs vietu sadalījums. Skatīi 2.4. tabulu.

2.4. tabula

Vietu sadalījums svarīgākajām problēmām, kas pasliktina dz̄ives kvalitāti pacientiem pirms operācijas, 3 mēnešus pēc operācijas un gadu pēc operācijas

\begin{tabular}{|l|c|c|c|}
\hline UW-QOL & $\begin{array}{c}\text { Vietu sadalījums } \\
\text { pirms operācijas }\end{array}$ & $\begin{array}{c}\text { Vietu sadalījums } \\
\text { trīs mēnešus pēc } \\
\text { operācijas }\end{array}$ & $\begin{array}{c}\text { Vietu sadalījums } \\
\text { gadu pēc operācijas }\end{array}$ \\
\hline Sāpes & 3 & 7 & $8={ }^{*}$ \\
\hline Izskats & 7 & $8=$ & 7 \\
\hline Aktivitāte & $4=$ & $5=$ & $4=$ \\
\hline Atpūta & $11=$ & 12 & $8=$ \\
\hline
\end{tabular}


2.4. tabulas turpinājums

\begin{tabular}{|l|c|c|c|}
\hline \multicolumn{1}{|c|}{ UW-QOL } & $\begin{array}{c}\text { Vietu sadalījums } \\
\text { pirms operācijas }\end{array}$ & $\begin{array}{c}\text { Vietu sadalījums } \\
\text { trīs mēnešus pēc } \\
\text { operācijas }\end{array}$ & $\begin{array}{c}\text { Vietu sadalījums gadu } \\
\text { pēc operācijas }\end{array}$ \\
\hline Rǐšana & $4=$ & $2=$ & 3 \\
\hline Košșāšana & 1 & 1 & 1 \\
\hline Runa & 8 & $2=$ & 2 \\
\hline Plecs & $11=$ & $10=$ & 12 \\
\hline Garša & $9=$ & 4 & $4=$ \\
\hline Siekalas & $9=$ & $10=$ & $8=$ \\
\hline Garastāvoklis & $4=$ & $8=$ & 6 \\
\hline Raizes & 2 & $5=$ & 6 \\
\hline
\end{tabular}

* = norāda, ka noteikto vietu pēc svarīguma dala vairāki domēni

No iegūtajiem rezultātiem redzams, ka pirms operācijas trīs svarīgākās problēmas pacientiem ir košļā̌sana, raizes, un sāpes. Trīs mēnešus pēc operācijas un gadu pēc operācijas trīs svarīgākās problēmas, kas pasliktina dzīves kvalitāti ir košlāšana, runa un rīšana. Analizējot visus kontroles laika posmus, redzams, ka košḷāšana ir vissvarīgākā problēma, kas pasliktina dzìves kvalitāti visa ārstniecības procesa laikā un tālākā pacienta novērošanas laika posmā.

\subsection{Mikrovaskulās rekonstrukcijas metožu pielietojums}

Visiem 142 pacientiem pētījuma grupā tika veikta mutes dobuma vienetapa rekonstrukcija ar mikrovaskulāriem lēveriem. Kopumā tika veiktas 111 mīksto audu rekonstrukcijas (78\%) un 31 kompleksa kaulaudu un mīksto audu rekonstrukcija (22\%).

Kopumā tika pārstādīti 144 mikrovaskulāri lēveri. No tiem 113 lēveri bija fasciokutāni lēveri, 31 osteokutāni lēveri.

Veicot mutes dobuma mīksto audu rekonstrukcijas, visbiežāk izmantotais fasciokutānais lēveris bija RAL - 69\% gadījumu, otrs biežāk pielietotais 
fasciokutānais lēveris bija LAL - 29\% gadījumu, un ALT tika pārstādīts 2\% gadījumu.

Veicot kompleksas mīksto un kaulaudu mutes dobuma rekonstrukcijas visbiežāk izmantotais osteokutānais lēveris bija mazā liela kaula lēveris (fibula) - 94\% gadījumu, savukārt 2\% tika pārstādīts scapulas lēveris un 2\% crista iliaca lēveris.

\subsection{Pētījuma grupas pacientu stacionārā pavadìtā laika analīze}

Operēto pacientu vidējais stacionārā pavadītais laiks bija 20,5 dienas (no 8-44 dienām). Netika konstatēta statistiski ticama korelācija $(\mathrm{p}>0,05)$ starp pacientu vecumu un stacionārā pavadīto laiku. Taču stacionārā pavadītais laiks korelēja ar tumora izmēru. Pacientiem ar lielāku audzēja izmēru pieauga stacionārā pavadīto dienu skaits (2.15. att.).

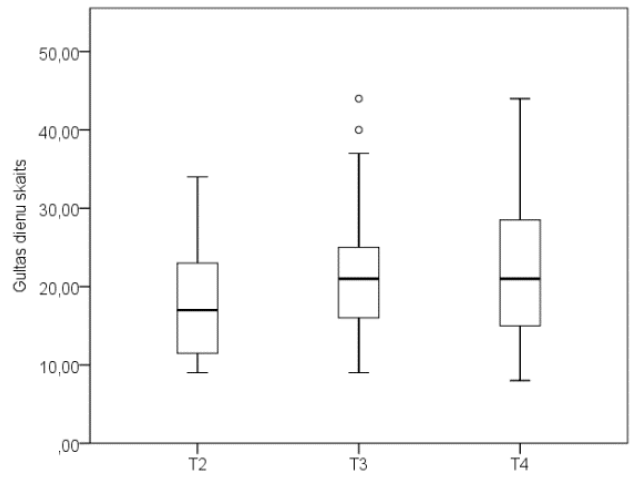

2.15. attēls. Stacionārā pavadīto gultas dienu skaita izmaiṇas pie dažādām T stadijām pētījuma grupas pacientiem 
Veicot korelācijas analīzi starp T un gultas dienu skaitu, ieguva pozitīvu, vāju un statistiski ticamu korelāciju $\left(r_{s}=0,16 ; p=0,04\right)$.

\subsection{Pēcoperāciju komplikāciju analīze pētījuma grupā}

Pēcoperācijas periodā izveidojušās komplikācijas nosacīit var iedalīit lielajās un mazajās komplikācijās. Ar lielajām komplikācijām saprot pacienta vispārējā veselības stāvokḷa pasliktināšanos pēcoperācijas periodā, kā rezultātā var iestāties pacienta nāve, un pārstādīto audu nekrozi, kas savukārt novēloti ārstēta var izraisīt virkni citu komplikāciju, kas var apdraudēt pacienta dzīvību.

No operētajiem 142 pacientiem pēcoperācijas periodā nomira 6 pacienti. 4 pacientiem tika veikta kompleksa mutes dobuma rekonstrukcija ar osteokutānu lēveri, bet diviem pacientiem tika veikta mīksto audu rekonstrukcija ar fasciokutānu lēveri.

No kopā pārstādītajiem 144 lēveriem 142 lēveri piedzija. Veiksmīgas lēveru pārstādīšanas procents sastāda 98,6\%. Trijiem pacientiem pēcoperācijas periodā parādījās asinsrites traucējumi pārstādītajā lēverī (2\%). Divos gadījumos tie bija osteokutāni lēveri (67\%), vienā gadījumā fasciokutāns lēveris (33\%). Visiem trim pacientiem tika konstatētas lēvera vēnu mikroanastomožu trombozes. Visos gadījumos tika veikta lēvera glābšanas revīzijas operācijas. Veicot brūces asinsvadu mikroanastomožu revīziju vienā gadījumā lēveri izdevās glābt. Neskatoties uz veikto revīziju diviem pacientiem pārstādītos mikrovaskulāros lēverus neizdevās glābt. Šiem pacientiem tika veikta atkārtota mutes dobuma rekonstrukcija ar cita veida mikrovaskulāru lēveri. Mazās komplikācijas operētajiem pacientiem bija brūces hematoma, šuvju dehiscence un margināla brūces nekroze. No 142 operētajiem pacientiem 17 pacientiem tika novērotas sekojošas komplikācijas. 14 gadījumos konstatēja hematomu, kas prasīja atkārtotu operāciju hematomas evakuācijai. Vienam pacientam bija 
intraorālās brūces šuvju dehiscence. Diviem pacientiem bija brūces margināla nekroze.

\subsection{Rekonstrukcijas veida ietekme uz pēcoperācijas komplikāciju biežumu}

Pacientiem pētījuma grupā, kuriem tika veikta mīksto audu rekonstrukcija - 91 pacientam (64,08\%) nebija komplikācijas, bet 20 pacientiem (14,08\%) bija komplikācijas. Savukārt no pacientiem, kuriem tika veikta kompleksa mīksto un kaulaudu rekonstrukcija - 20 pacientiem (14,08\%) nebija komplikācijas, bet 11 pacientiem $(7,75 \%)$ bija komplikācijas. Veicot statistisko analīzi starp rekonstrukcijas veidu un komplikācijām, konstatēja statistiski ticamu asociāciju $(\mathrm{p}=0,03)$. Pacientiem ar komplekso rekonstrukciju izredzes, ka būs komplikācijas ir 2,50 (95\% TI: 1,03-6,04) reizes biežāk salīdzinājumā ar mīksto audu rekonstrukciju. 


\section{DISKUSIJA}

Mutes vēzim raksturīgā asimptomātiskā gaita un agrīnā tendence metastazēties kakla limfmezglos rada saslimšanas novēlotu diagnostiku. Valstīs ar attīstìtu ekonomiku mutes vēzis vēlīnās stadijās tiek diagnosticēts salīdzinoši retāk, nekā valstīs ar vāji attīstîtu ekonomiku. Tas skaidrojams ne tikai ar veselības aprūpes pieejamību, bet arī ar sabiedrības veselības izglītību. Audzēja klīniskā gaita diemžēl joprojām rada problēmas agrīnai diagnostikai, kā rezultātā arī attīstîtās valstīs mutes vēzis vēlīnās stadijās saglabā ievērojamu īpatsvaru. Saskaņā ar SPKC datiem 2016. gadā 66\% pacientu tika diagnosticēts mutes vēzis vēlīnā stadijā.

Pasaulē, pēc literatūras datiem, vidējais pacientu saslimšanas vecums ar mutes vēzi, ir 60 gadi. Pētījumā visu iekḷauto pacientu vidējais vecums bija 58 gadi (no 30 līdz 81 gadam), sievietēm vidējais vecums bija par gadu vairāk 59 gadi. Salīdzinot mūsu pētījuma datus ar SPKC datiem redzams, ka arī mūsu pētījumā abu dzimumu incidences būtībā sakrīt par attiecīgo laika periodu.

Pasaulē vīriešiem mutes vēzis ir trīs reizes biežāk nekā sievietēm (Weatherspoon, Chattopadhyay et al. 2015). No mūsu pêtījumā ieļautajiem pacientiem vīrieši bija 3,5 reizes biežāk pētījuma grupā un 5 reizes biežāk kontroles grupā. Analizējot patomorfologisko audzēju veidu, Latvijas populācijā audzēja veids neatšksiras no pasaules literatūras datiem (Montero and Patel 2015), jo pētījuma grupā 99\% tika diagnosticēts plakanšūnu vēzis, savukārt kontroles grupā plakanšūnu vēzis bija visos gadījumos (100\%).

Ja analizē audzēja lokalizāciju mutes dobumā, tad mūsu pētījuma dati atšķirās no citu valstu datiem. Pēc literatūrā pieejamiem datiem $90 \%$ audzēju lokalizējas mēlē un mutes pamatnē (Montero and Patel 2015), tomēr mūsu pētījuma grupā audzējs lokalizējās mutes pamatnē un mēlē $75 \%$ gadījumu. Savukārt kontroles grupā 53\% gadījumu audzējs lokalizējas mutes pamatnē un 
mēelē. Tas skaidrojams ar to, ka sākumstadijās tumora primāro lokalizāciju parasti ir viegli noteikt, neliela čūla ar skaidri izteiktām robežām parasti nerada problēmas lokalizēt tumoru un to pareizi definēt. Savukārt vēlīnās stadijās, kad audzējs skāris vairākas struktūras, piemēram, mēli, mutes pamatni un smaganas vai vaigu, ir novērojama audzēja destrukcija ar lokālu iekaisumu, primārā audzēja lokalizāciju precīzi definēt bieži vien ir sarežğîti.

Analizējot audzēju patomorfologiskos rezultātus, jāsecina, ka TNM sistēma ḷauj precīzi novērtēt primārā audzēja izmērus, limfmezglu stāvokli un distanto metastāžu esamību vai neesamību. Mūsu pētījums rāda, ka pacientiem ar mutes audzēju vēlīnā stadijā, nevienā gadījuma netika mainīta diagnoze pēc gala histologiijas atbildes saņemšanas, kas liecina, ka pieredzējušu speciālistu rokās šīs slimības primārā diagnostika ir samērā precīza.

Primārā tumora izvērtēšana ir svarīgs nosacījums veiksmīga ārstēšanas plāna izstrādē. Precīzi izvērtējot audzēja lokalizāciju un saistību ar apkārtējām struktūrām iespējams pareizi plānot operācijas apjomu, nepieciešamās rekonstrukcijas veidu un papildus manipulācijas, kas nodrošinās viegli un droši vadāmu pēcoperācijas atlabšanas periodu. Neskatoties uz mutes dobuma komplicēto anatomisko uzbūvi, plašās mutes dobuma rekonstrukcijas iespējas dod ķirurgam iespēju radikāli ekscidēt audzēju. Mūsu pētījuma dati rāda, ka pētījuma grupā tikai četriem pacientiem ekscīzijas līnijas bija pozitīvas. Pārējos 138 gadījumos audzējs tika radikāli iznemts veselo audu robežās.

Audzēja lokalizācija mutes dobumā nav svarīga tikai primārā tumora ārstēšanas taktikas izstrādei, bet arī kakla limfmezglu metastāžu izvērtēšanai. Kā liecina literatūras dati (Shah, Candela et al. 1990, Bittar, Ferraro et al. 2016), kakla limfmezglu stāvoklis un to precīza diagnostika visvairāk ietemē pacienta dzīvildzes prognozi. Zinot veidu, kā notiek metastazēšanās kakla limfmezglos, iespējams izvēlēties visatbilstošāko kakla disekcijas veidu. Pacientiem ar klīniski negatīviem kakla limfmezgliem vislielākā iespēja metastāzēm ir I-III līmenī 
(Shah, Candela et al. 1990). Reti metastāzes atrodamas arī IV līmen̄i, īpaši, ja audzējs lokalizējas mēles priekšêjā dal̦ā. Metatāzes V līmenī ir retas (1\%), pat ja pacientam ir kakla metastāzes citos līmen̦os. No visiem mutes dobuma audzējiem tieši mēles audzējiem ir vislielākā tieksme metastazēties kakla limfmezglos un audzēja biezums ir svarīgākais prognostiskais faktors izvērtējot audzēja risku metastazēties (Fakih, Rao et al. 1989, Montero and Patel 2015). Mūsu pētījums apstiprina to, ka mēlē lokalizētam audzējam ir augsta tieksme metastazēties kakla limfmezglos. Kontroles grupā kakla limfmezglos metastāzes bija 89\%, bet pētījuma grupā $86 \%$ gadījumu.

Shah J.P. et al. norāda, ka audzējiem, kuru dziḷums nepārsniedz 2 mm kakla metastazēšanās risks kakla limfmezglos ir 13\%, ja tumora dzilıums sasniedz 3-8 mm, tad metastazēšanās risks kakla limfmezglos ir 46\%, bet, ja vairāk nekā $8 \mathrm{~mm}$, tad metastazēšanās risks kakla limfmezglos sasniedz 65\%. Būtu interesanti ar šiem rezultātiem salīdzināt mūsu pētījuma datus, bet diemžēl Latvijā veiktās patomorfologiiskās analīzes visbiežāk apraksta tumora izmēru, bet ne biezumu, tāpēc izpētît saistību starp tumora biezumu un metastazēšanās biežumu kakla limfmezglos nebija iespējams.

Analizējot mutes vēža lokalizāciju ar tendenci metastazēties kakla limfmezglos, objektīvi varēja izvērtēt tikai pētījuma grupu, jo kontroles grupā netika veiktas kakla limfadenektomijas. Savukārt pētījuma grupā 139 pacientiem tika veikta kakla limfadenktomija, un tikai trijiem pacientiem netika veikta kakla limfadentomija.

Interesanti, ka no 73 pacientiem, kas pētījuma grupā bija ar diagnosticētu audzēju mēlē, kakla limfmezglu metatstāzes tika diagnosticētas lielākajai daḷai pacientu - 50 pacientiem, no kuriem T1 bija 25 pacientiem, T2 bija 24 pacientiem un T3 bija vienam pacientam. Savukārt 23 pacientiem metatstāzes kakla limfmezglos diagnosticētas netika. 
Kontroles grupā no 43 pacientiem 28 pacientiem audzēja lokalizācija bija mēle. No šiem 28 pacientiem trīs pacientiem kakla limfmezglos metatstāzes netika konstatētas. 11 pacientiem tika diagnosticēts N1, 13 pacientiem tika diagnosticēts N2, un vienam pacientam N3. Iegūtie dati liecina, ka audzējam lokalizētam mēlē ir augsta tieksme metastazēties kakla limfmezglos.

Lai izvērtētu iespējamo ietekmes faktoru saistību ar operāciju rezultātiem un komplikāciju biežumu tika analizētas pacientu blakussaslimšanas. Pētījuma grupā no 142 pacientiem tikai $20 \%$ pacientu netika konstatētas blakussaslimšanas. $80 \%$ pacientu tika konstatētas 224 blakus saslimšanas. Vairāk nekā pusei no pētījuma grupas bija vairāk kā viena blakussaslimšana. Biežākā blakussaslimšana bija smēķētāja bronhīts, kas sasniedza 36\% no pētījuma grupas pacientu skaita. Tas, ka smēķētāja bronhīts ir līderis starp blakusslimībām nav pārsteigums, zinot, ka mutes vēža viens no galvenajiem etiologiiskajiem faktoriem ir smēķēšana (Lambert, Sauvaget et al. 2011, Kumar, Nanavati et al. 2016).

Otrā biežākā blakusslimība bija arteriālā hipertensija 23\% un koronārā slimība 16\% pacientu. Tas korelē ar šo saslimšanu īpatsvaru populācijā gan Latvijā, gan pasaulē. Pārējo saslimšanu īpasvars bija nenozīmīgs, taču būtisks ir fakts, kas 2\% pacientu pētījuma grupā tika diagnosticēts un ārstēts vēl viens citas lokalizācijas audzējs, pirms tika uzstādīta mutes vēža diagnoze. Pacientiem ar mutes vēzi risks iegūt otru primāru galvas un kakla vēzi ir apmēram 4-7\% (Leon, Martinez et al. 2012), taču nav precīzu datu, cik liels ir risks slimot ar vēl vienu citas lokalizācijas vēzi.

Mūsu pētījumā ietverto visu ārstēto pacientu dzīvildzes mediāna bija 2,25 gadi. Salīdzinot dzīvildzi starp vīriešiem un sievietēm nākas konstatēt, ka sievietēm divu gadu dz̄ivildze pētījuma grupā ir par 5\% augstāka nekā vīriešiem, bet 5 gadu dzīvildze ir par 3\% augstāka, kas nav būtiska atšķirība. Savukārt kontroles grupā sievietēm 2 gadu dzīvildze joprojām ir 65\%, bet vīriešiem vairs 
tikai 25\%. Kontroles grupā piecus gadus nenodzīvoja ne vīrieši, ne sievietes. Rezultāti liek secināt, ka pacientu dzimums būtiski neietekmē dzīvildzi. 40\% atšķirība kontroles grupā 2 gadu dzīvildzē skaidrojama ar nelielo sieviešu īpatsvaru kontroles grupā. Ja vīriešiem pētījuma un kontroles grupās izdevās iegūt statistiski ticamu atšksirību, tad sievietēm statistiski ticamus un korektus aprēķinus nevarēja veikt, jo bija pārāk mazs pacientu skaits.

Lai izvērtētu, vai ķirurğiski ārstēto pacientu dz̄ivildze ir ilgāka, nekā pacientiem, kuriem ķirurǵiska ārstēšana netika pielietota, tika salīdzinātas pētījuma grupas un kontroles grupas dzīvildzes.

Mūsu pētījums rāda, ka pacientiem, kuriem tika pielietota tikai staru terapija ar vai bez ķ̄imijterapijas, 2 gadu dz̄ivildze bija par 30\% zemāka, nekā pacientiem, kas tika operēti. No pacientiem, kuriem tika veikta audzēja ekscīzija, piecus gadus nodzīvoja 42\%. No 43 pacientiem, kas tika ārstēti ar staru terapiju, piecus gadus nenodzīvoja neviens pacients.

Tas apstiprina faktu, ka ķirurgisiska ārstēšana joprojām ir pamatārstēšanas metode pacientiem ar mutes vēzi (Smee, Broadley et al. 2012) un pacienti ir jāmotivē neatteikties no operatīvas terapijas, jo tas var būtiski pagarināt viṇi dzīvildzi.

Analizējot audzēja izmēra ietekmi uz pacientu dz̄ivildzi, konstatēja, ka pacientiem ar T3 audzēju 2 gadu dzīvildze pētījuma grupā bija par 25\% augstāka nekā kontroles grupā, bet 5 gadu dzīvildze pētījuma grupā sasniedza $41 \%$, savukārt kontroles grupā neviens pacients piecus gadus nenodzīvoja. Pacientiem ar T4 pētījuma grupā 2 gadu dzīvildze bija par 39\% augstāka nekā kontroles grupā. Savukārt 5 gadu dzīvildze pētījuma grupā bija 50\%, bet kontroles grupā neviens pacients nenodzīvoja piecus gadus. Salīdzinot T3 ar T4 dzīvildzi redzams, ka audzēja izmēram nav izšķiroša loma pacientu dz̄ivildzē. Tas apstiprina faktu, ka audzēja izmēram nav izšķiroša nozīme pacienta dz̄ivildzē (Punhani, Dongarwar et al. 2017). 
Analizējot audzēja diferenciācijas pakāpes ietekmi uz pacientu dzīvildzi, konstatēja, ka audzēja diferenciācijas pakāpe ir būtisks prognostisks faktors, bet ne izšķirošs. Kontroles grupā 2 gadu dzīvildze pacientiem ar Grade 1 bija par 20\% zemāka, nekā Grade 3, kas norāda, ka staru terpija ir efektīva ārstēšanas metode zemu diferencētiem audzējiem, un tā ir indicēta kā papildus ārstēšana arī pacientiem, kam veikta ķirurğiska ārstēšana. Pētījuma grupā pacientiem ar augstas diferenciācijas pakāpes (Grade 1) audzēju divu gadu un piecu gadu dzīvildze bija 100\%. Pacientiem ar zemas diferenciācijas pakāpes audzēju (Grade 3) 5 gadu dzīvildze salīdzinot ar 2 gadu dzīvildzi, lai arī samazinās par $16 \%$, tomēr saglabā 45\%, kas ir par trīs procentiem ilgāk nekā kopēja dzīvildze pētījumā.

Montero un Patel apraksta, ka pacietam ar mutes vēzi un ar metastāzēm kakla limfmezglos, izdz̄ivošanas iespējas samazinās par 50\%, salīdzinot ar pacientu, kuram ir identisks mutes audzējs, bet nav kakla limfmezglu metastāžu (Montero and Patel 2015). Pētījumā apkopotie dati apstiprina, ka primārā tumora izmēram un lokalizācijai nav izšksiroša nozīme dzīvildzes prognozē, bet izšķiroša nozīme ir metastāžu esamība kakla limfmezglos (Shah, Candela et al. 1990).

Scully et al. un Kumar et al. apraksta audzēja lokalizācijas svarīgo lomu pacienta prognozē (Scully and Bagan 2009, Kumar, Nanavati et al. 2016). Audzēju lokalizācijai ir saistība ar audzēja tieksmi metastazēties kakla limfmezglos (Junior, Barboza et al. 2008). Pēc daudzu autoru publikācijām audzēji, kas lokalizēti mēlē ir ar vislielāko tieksmi metastazēties kakla limfmezglos (Sessions, Spector et al. 2002, Noguti, De Moura et al. 2012, Lin, Jen et al. 2013, López-Cedrún and Andrés de Llano 2015, Le Campion, Ribeiro et al. 2017). Analizējot mutes audzēja lokalizācijas saistību ar kakla limfmezgliem, konstatējām, ka gan pētījuma grupā, gan kontroles grupā audzēji, kas lokalizēti mēlē ir ar augstu metastazēšanās tieksmi. Kontroles grupā tas bija par 35\% augstāks un sasniedza 89\% gadījumu. 
Lai izvērtētu audzēja ekscīzijas līniju ietekmi uz ķirurǵiskās ārstēšanas rezultātu un saistību ar dzīvildzi, tika izvērtēti pacienti ar tīrām ekscīzijas līnijām un pacienti ar audzēja šūnām ekscīzijas līnijās. To, cik svarīga ir audzēja ekscīzija veselo audu robežās, vairs neviens neapšauba (Franceschi, Gupta et al. 1993, Sessions, Spector et al. 2002, Luryi, Chen et al. 2014, Montero and Patel 2015, Chen, Lai et al. 2016, Stathopoulos and Smith 2017). Tas ir pamats veiksmīgam ārstēšanas rezultātam onkoķirurǵijāa Mūsu pētījums norāda, ka audzēja ekscīzijas līnijām ir noteicoša loma pacienta dzīvildzē. Pacientiem kuriem ekscīzijas līnijas bija negatīvas (tīras) 5 gadu dzīvildze sasniedza $43 \%$. Savukārt no pacientiem, kuriem ekscīzijas līnijas bija pozitīvas (audzēja šūnas ekscīzijas līnijās), neviens nenodzīvoja pat divus gadus.

Pētîjuma grupā mīksto audu mutes dobuma rekonstrukcijas tika veiktas 3/4 pacientu, savukārt kompleksa mīksto un kaulaudu rekonstrukcija tika veikta ceturdaļai pacientu. Rekonstrukciju veidu attiecība skaidrojama ar centieniem mutes dobuma rekonstrukcijai rast optimālo risinājumu. No 113 pārstādītajiem fasciokutāniem lēveriem RAL tika izmantots 69\% gadījumu. Lai arī RAL ir ideāls lēveris mutes dobuma mīksto audu rekonstrukcijai, donorvietas problēmas tiek uzsvērtas kā galvenais ši lēvera trūkums. Lai to veiktu visbiežāk tiek izmantota plānināta vai pilna biezuma ādas trasnplantāta pārstādīšana (ADP). Literatūras dati liecina, ka ADP nepiedzīst līdz pat 53\%, un cīpslas ir atsegtas 33\% gadījumu (Swanson, Boyd et al. 1990). Mūsu pētījuma grupas pacientiem, kuriem tika veikta RAL transplantācija visiem pacientiem tika veikta donorvietas slēgšana ar ADP. Lai arī vairākiem pacientiem bija novērojama ADP lizēšanās un sekundāra dz̄̄̌sana, nevienam pacientam nebija nepieciešama ķirurǵiska donorvietas ārstēšana. Tas tika sasniegts pateicoties lēvera projekcijas vietas pareizai izvēlei.

Literatūrā aprakstīti daudz dažādu osteokutānu lēveru izmantošana. Apasiņota riba, lāpstiņa vai iegurņa kauls var tik izmantoti, kad nepieciešama 
lielu kaulu defektu rekonstrukcija, taču populārākais un visplašāk izmantotais lēveris ir apakštilba mazais liela kauls. Pateicoties mazā liela kaula periostālai asinsritei un ādas perforatoram, kuru izmantojot, var rekonstruēt mutes dobuma mīksto un kaulaudu defektus, mazā liela kaula lēveris ir kḷuvis par "zelta standartu" visā pasaulē (Lopez-Arcas, Arias et al. 2010).

Mūsu pētījuma grupā tika pārstādīti 31 osteokutāni lēveri. 98\% gadījumu tika izmantots mazais liela kauls, un tikai $4 \%$ cita veida osteokutāns lēveris. Vienā gadījumā tika izmantots lāpstiņas osteokutāns lēveris un vienā gadījumā crista iliaca osteokutāns lēveris. Mazā liela kaula lēvera popularitāti nodrošina konstantā anatomija ar plānu ādas saliṇu, kas ir ideāla mutes dobuma mīksto audu defektu rekonstrukcijai. Lāpstiņas lēveris ir piemērots augšžokļa rekonstrukcijām, jo tā plakanā forma līdzinās cieto aukslēju formai. Diemžēl lāpstiņas kauls ir plāns praktiski visā laukumā, tas nenodrošina pietiekamu kaula apjomu, kas liedz vēlāk veikt zobu implantāciju. Otrs lēvera trūkums ir tas, ka lāpstiņas lēvera ādas daļa principā ir paraskapulārs vai skapulārs lēveris, kas bieži ir ar biezu zemādas taukaudu slāni. Lai nodrošinātu normālu mutes dobuma formu un funkciju, nepieciešama lēvera plānināšana.

Grohmann et al. salīdzināja mazā liela kaula lēveri, crista iliaca lēveri un skapulāro lēveri. Autors veica slodzes testu līkiem, kuriem bija veikta apakšžokļa rekonstrukcija ar augstāk minētajiem lēveriem. Pētījums apstiprināja, ka apakšžoklis pēc rekonstrukcijas ar mazā liela kaula lēveri uzrāda vislabāko rezultātu slodzes testā (Grohmann, Raith et al. 2015).

Apskatot literatūras datus, lēveru izdzīvotības procents ir dažāds. Mazās pētījuma grupās tas var sasniegt pat 100\% (Sugiura, Sarukawa et al. 2018), taču lielās pētījuma grupās tas svārstās no 90\% līdz 93\% (Lopez-Arcas, Arias et al. 2010, Gerressen, Pastaschek et al. 2013, Shroff, Nair et al. 2017, Liang, Yu et al. 2018) ar augtāku izdzīvošanas tendenci tieši fasciokutāniem lēveriem. Tas skaidrojams ar salīdzinoši vienkāršāku operāciju un īsāku operācijas laiku. 
Analizējot lēveru izdzīvotību pētījuma grupā konstatēja, ka visu pārstādīto lēveru kopējais izdzīvošanas procents bija 98,6\%, kas ir augstāks, salīdzinot ar literatūras datiem. Mūsu pētījuma dati liek secināt, ka lēveru izdzīvošanas procents ir saistīts ar ķirurgu profesionalitāti un nepieciešamību šāda veida operācijas veikt regulāri, kā rutīnas procedūru, ar pieteikoši lielu pacientu plūsmu.

Analizējot pēcoperācijas komplikācijas pētījuma grupā, mirstība sasniedza 2,8\%. Salīdzinot literatūrā aprakstīto pēcoperācijas mirstību, kas var sasniegt līdz pat 20\% (Mulvey, Brant et al. 2017), mūsu pētījuma grupā pēcoperācijas mirstība nepārsniedz literatūrā aprakstīto letalitāti. Analizējot nāves cēloṇus pētîjuma grupā mirušajiem pacientiem, $-50 \%$ gadījumu nāves iemesls bija akūta plaušu trombembolija. Salīdzinot ar literatūras datiem, postoperatīvās plaušu komplikācijas var sasniegt līdz pat 18,8\%, bet mirstība sasniedz 6\% (Loeffelbein, Julinek et al. 2016). Mūsu pētījumā plaušu trombembolijas biežums un ar to saistītā letalitāte ir zemāka nekā vidēji pētījumā aprakstîtā mirstība no plaušu trombembolijas. Izpētot nosacīti mazās komplikācijas, konstatējām, ka tās bija 11,9\% pacientu. Literatūras dati norāda, ka asiņošana var sasniegt līdz 6\% gadījumus (Tsai, Chang et al. 2012, Pollei, Hinni et al. 2013), bet fistulas, kas ir sekas sekundārai brūces dzīšanai, var sasniegt līdz 10\% (Lodders, Schulten et al. 2016, Zhou, Zhang et al. 2017). Mūsu pētījuma grupā no 142 pacientiem asiņošanas procents bija augstāks $(9,8 \%)$, nekā literatūrā aprakstīts. Savukārt, sekundāra dzīšana pēcoperācijas periodā tika novērota 2,1\% gadījumu no 142 pacientiem, kas ir labāks rādītājs, salīdzinot ar literatūrā aprakstīto. Apkopojot pētījuma grupas datus un veicot statistisko analīzi starp rekonstrukcijas veidu un komplikācijām, konstatēja statistiski ticamu saistību $(\mathrm{p}=0,03)$. Pacientiem ar kompleku mutes dobuma rekonstrukciju izredzes, ka būs komplikācijas ir 2,50 reizes lielākas, salīdzinot ar pacientiem, kuriem tiek veikta mīksto audu rekonstrukcija (95\% TI; 1,03-6,04). 
Lai arī pielietotās ārstēšanas metodes ir ievērojami attīstîjušās mutes vēža ārstēšanā, joprojām pacientu dzīvildze vēīnās stadijās nav būtiski mainījusies. Tāpēc arvien svarīgāku lomu ārstēšanas rezultāta izvērtēšanā ieṇem dzìves kvalitātes novērtējums. Izprotot šo faktoru ietekmi uz ārstēšanas procesu un pacientu, būtu vēlams ārstēšanas plānu veidot tā, lai pēc iespējas mazinātu ārstēšanas ietekmi uz pacienta dzīves kvalitāti (Murphy, Ridner et al. 2007).

Literatūrā ir daudz DZK pētījumu pacientiem ar mutes vēzi, bet pamatā tie ir pētījumi, kuros tiek analizēta DZK pacientiem ar mutes vēzi, neiedalot sīkāk pacientus pa stadijām. Ir salīdzinoši maz pētījumu, kur tiek analizēta DZK pacientiem ar mutes vēzi vēlīnās stadijās. Vēlīnas stadijas mutes vēzis ir saistīts ar būtisku funkcionālu bojājumu, kas varbūt saistīts ar audzēju vai pielietoto ārstēšanu. Publicētie dati rāda, ka plaša tumora ekscīzija un nepieciešamība veikt mutes dobuma rekonstrukciju ir saistīta ar sliktu DZK. Īpaši uzsverot runas un rīšanas funkciju (Klozar, Lischkeova et al. 2001, Buchmann, Conlee et al. 2013, Milet, Mallet et al. 2010, Gobbo, Bullo et al. 2016). Protams, iegūtie dati var būt atšķiirīgi līdzịgās pacientu grupās pat viena reǵiona vai medicīniskās institūcijas ietvaros. Tas saistīts ar ārstējošā ārsta pieredzi un ķirurğisko tehniku.

Apkopojot datus ir redzams, ka vispārējā DZK ir ievērojami uzlabojusies, pacienti savu vispārējo veselības stāvokli vērtē kā labu. B un C domēni, kas raksturo DZK pēc ārstēšanas, 75\% pacientu savu ar veselības stāvokli saistīto dz̄ives kvalitāti atzīmē kā izcilu vai ļoti labu.

Analizējot ar slimību saistîtos domēnus, dati ir atškirīgi. Uzlabojums ir novērojams sāpju, aktivitātes, garastāvokḷa un raižu domēnos. Izmaiņas nav novērotas pleca un siekalu domēnos, bet pasliktināšanās novērojama izskata, atpūtas, rīšanas, runas, garšas un košļāšanas domēnos. Matsui et al. secināja, ka ideāla rekonstrukcijas metode ir tā, kura nodrošina vismazāko ietekmi uz funkcionalitāti (Matsui, Ohno et al. 2007). Tas īpaši attiecināms uz pacientiem, kam jau pirms operācijas prognozējama būtiska ietekme uz runas funkciju. Tika 
konstatēts, ka runa vismazāk tika ietekmēta pacientiem, kuriem tika veikta primāra brūces slēgšana, salīdzinot ar pacientiem, kuriem tika izmantoti jebkāda veida lēveri. Tāpat joprojām pastāv diskusija par mēles rekonstrukcijas ar mikrovaskulāru lēveri, lietderību. Chen et al. savā publikācijā izteica šaubas par mēles rekonstrukcijas nepieciešamību (Chen, Zhang et al. 2002). To apšaubīja Hsiao et al. savā pētījumā, norādot, ka pacientiem, veicot mēles rekonstrukciju, lai arī runas funkcijas uzlabojums ir nepietiekošs, rīšanas funkcija ievērojami uzlabojas (Hsiao, Leu et al. 2003). Savukārt Biglioli, izmantojot inervētus mikrovaskulārus lēverus, sasniedza labus rezultātus, norādot, ka pacientiem bija labi rezultāti izvērtējot gan rīšanas, gan runas funkciju, līdz ar to uzlabojas DZK rādītāji (Biglioli, Liviero et al. 2006).

Ja izvērtē labāko iespējamo atbilžu procentuālo īpatsvaru, tad būtisks uzlabojums redzams sāpju domēnā, kamēr mērens uzlabojums - garastāvokḷa domēnā. Bez izmaiṇām ir siekalu un pleca domēni. Ja siekalu domēns parasti norāda par staru terapijas ietekmi uz dzīves kvalitāti, tad pleca domēns saistīts ar kakla limfadenektomiju. Rathod et al. atzīmēja, ka kakla disekcijas ietekme uz DZK atspoguļojas, samazinot punktu skaitu pleca, izskata, atpūtas un aktivitātes domēnos (Rathod, Livergant et al. 2015). Labāko atbilžu procentuālais īpatsvars nedaudz ir samazināts aktivitātes un raižu domēnos, bet mēreni samazināts izskata, atpūtas, rīšanas un runas domēnos. Būtiski labāko iespējamo atbilžu procentuālais īpatsvars ir samazinājies garšas un košļā̌sanas domēnos. Mūsu pētījuma rezultāti apstiprina literatūras datus, tāpat norāda, ka vislielākais pasliktinājums redzams koşlāăanas un garšas domēnos. Tas skaidrojams ar zobu zudumu un mēles dal̦ēju vai pilnīgu rezekciju operācijas laikā.

Interesanti, ka domēnos, kuros tika novērota būtiska uzlabošanās vai pasliktināšanās, tas tika konstatēts jau 3 mēnešu kontroles punktā, bet 12 mēnešu kontroles punktā tika novērota vien viegla korekcija. Savukārt, domēnos, kas palika nemain̄̄gi pētījuma laikā, 3 mēnešu kontroles punktā tika novērota viegla 
pasliktināšanās. Rogers et al. novēroja galvenos prognostiskos faktorus, kas akumulējas un ietekmē DZK rezultātu. Tie ir audzēja izmērs, klīniski funkcionālais stāvoklis un operācijas veids. Viņš novēroja, ka DZK ir tendence pasliktināties pēc operācijas līdz 6 mēnešiem, kam seko mērens uzlabojums līdz vienam gadam (Rogers, Lowe et al. 2002). Autors atzina, ka svarīgi ir novērtēt pacienta izejas veselības stāvokli, jo bieži vien pacients jau ir ar funkcionālu deficītu pirms vēl sākta ārstēšana. Tāpat jāsaprot, ka atgriešanās "izejas punktā” vēl nenozīmē labu DZK. Daudzi pētījumi norāda jau uz izmainītu DZK vēl pirms sākta ārstēšana, kas saistīta ar nesen diagnosticēto saslimšanu un pacienta psihoemocionālo stāvokli.

Jautājot pacientiem atzīmēt trīs vissvarīgākās problēmas pirms operācijas, pacienti atzīmēja košļāšanu, raizes un sāpes, tomēr 3 mēnešus un 12 mēnešus pēc operācijas svarīgākās problēmas bija košlāšana, runa un rīšana. Kā redzams, košlāăana ir svarīgākais DZK pazeminošais domēns.

Pacientu dzimums arī ieņem svarīgu lomu DZK prognozē. Pacientiem ar mutes vēzi bieži novērojams distresa sindroms. Tas biežāk attīstās tieši vīriešiem, un tā mazināšanās vīriešiem notiek retāk nekā sievietēm (Frampton 2001, Buchmann, Conlee et al. 2013). Vecuma ietekme uz DZK ir pretrunīga. Literatūrā sastopami pētījumi, kas liecina par zemāku toleranci un ietekmi uz dzīves kvalitāti vecumā (Milet, Mallet et al. 2010). Ir publikācijas, kas secina, ka pacienta vecums neietekmē DZK rezultātus (Gobbo, Bullo et al. 2016). Mūsu pētījums norāda, ka pacienta vecums būtiski neietekmē pacienta DZK. Rezultāti liek domāt par tendenci, ka blakusslimībām un pacienta dzimumam ir lielāka tieksme ietekmēt DZK. De Araújo $J r$ et al. norādīja, ka izšķirošais DZK pasliktinošais faktors ir audzēja lokalizācija. Pēc autora domām mēle, mīkstās aukstlējas un mutes pamatne ir ar vissliktāko prognozi mutes dobuma plakanšūnu vēzim (Junior, Barboza et al. 2008). Salīdzinot trīs vissvarīgākās 
problēmas, kas pacientiem ir aktuālas un būtiski ietekmē DZK, jāsecina, ka mūsu pētījuma pacientiem ir ḷoti līdzīgas problēmas, kādas tās ir aprakstītas literatūrā. 


\section{SECINĀJUMI}

1. Salīdzinot 2 gadu dz̄ivildzi pacientiem ar ielaistu mutes vēzi, kuriem tika pielietota ķirurgíska mutes vēža ārstēšana, ar pacientiem, kuriem staru terapija bija pamata ārstēšanas metode, 2 gadu dzīvildze operētajiem pacientiem bija par 30\% biežāk.

2. Savukārt 5 gadu dzīvildzes dati rāda, ka staru terapija nenodrošina pacientiem ar mutes vēzi vēlīnās stadijās 5 gadu dzīvildzi, atšķirībā no ķirurǵiskas ārstēšanas, kas nodrošina piecu gadu dzīvildzi $42 \%$ gadījumu.

3. Būtiskākie faktori, kas statistiski ticami ietekmē pacientu dzīvildzi ir rezekcijas līniju stāvoklis un metastāžu esamība kakla limfmezglos.

4. Pastāv saistîba starp mutes dobuma rekonstrukcijas veidu un pēcoperācijas komplikāciju biežumu. Pacientiem, veicot kompleksu mutes dobuma rekonstrukciju, iespēja attīstīties komplikācijām ir 2,5 reizes lielāka, nekā veicot vienkāršu mutes dobuma rekonstrukciju.

5. Ielaista mutes vēža pacientiem pēc ķirurǵiskas ārstēšanas ir novērojams vispārējās dzīves kvalitātes ievērojams uzlabojums, tomēr ar slimību saistītā dzīves kvalitāte ir svārstīga un ar negatīvu tendenci. 


\section{PUBLIKĀCIJAS UN ZIN̦OJUMI PAR PĒTĪJUMA TĒMU}

\section{Publikācijas par darba tēmu:}

Pastars, K., Zarins, J., Tars, J., Ivanova, A., Skagers, A. 2018. Microsurgical reconstruction of oral defects with free flaps for patients with oral cancer: an 8 year experience with 153 consecutive cases. Stomatologija, Baltic Dental and Maxillofacial Journal, 20, 39-42.

Pastars, K., Zarins, J., Tars, J., Ivanova, A., Skagers, A. 2018. Oral reconstruction with free lateral arm flap analysis of complication and donor site morbidity for patients with advanced stage oral cancer. Proceedings of Latvian Academy of Sciences. Section B, Vol. 72 (2018), No. 5 (716), 20-30.

Pastars, K., Tars, J., Ivanova, A., Zarins, J., Sivins, A., Skagers, A. 2015. Reconstruction of esophagus with free jejunal graft. Acta Chirurgica Latviensis No. 15/2, 21-24.

Pastars, K. Реконструкция дефекта пищевода с использованием кишечного трансплантата на сосудистой ножке. 2015. Orenburg Medical Journal No. 2.

\section{Ziṇojumi starptautiskās konferencēs un kongresos}

Pastars, K., Keirans, A., Pilaps, Z., Kazanceva, A., Tars, J. Lower face reconstruction with double skin paddle free fibula. Case report. 2010. The $4^{\text {th }}$ World Congress of International Federation of Head and Neck Oncologic Societies, Seoul, South Korea.

Kazanceva, A., Tars, J., Kornevs, E., Sokolovs, J., Pastars, K., Groma, V. 2010. Clinical and Pathomorphological Results of 30 Patients with Head and 
Neck Reconstructions Using Microvascular Flaps and Bone Graft. Eur Arch Otorhinolaryngol.

Kazanceva, A., Tars, J., Kornevs, E., Lauskis, G., Pastars, K., Keirans, A., Groma, V. Clinical and pathomorphological results of 50 patients with head and neck reconstructions using microvascular flaps and bone grafts. 2010. Proc. $7^{\text {th }}$ Congr. Baltic Association Maxillofacial and Plastic Surgery, 44-45.

Kazanceva, A., Tars, J., Pastars, K., Groma, V., Kornevs, E., Keirans, A. 2010. Clinical and Pathomorphological Results of 40 Patients with Head and Neck Reconstructions Using Microvascular Flaps and Bone Grafts. Abstracts of the $4^{\text {th }}$ World Congress of International Federation of Head and Neck Oncologic Societies, 113.

Pastars, K., Keirans, A., Tars, J., Kazanceva, A. 2010. Head and neck soft tissue defect reconstruction with free flaps after tumor extirpation. 7th Congress of Baltic Association for Maxillofacial and Plastic Surgery.

Pastars, K., Keirans, A., Tars, J., Kazanceva, A., Kornevs, A., Lauskis, G. 2010. Reconstruction of mandible defects with vascularised and nonvascularized bone grafts. $7^{\text {th }}$ Congress of Baltic Association for Maxillofacial and Plastic Surgery.

Pastars, K., Tārs, J., Zariņš, J., Ivanova, A., Keirāns, A., Pauliṇa, B., Pīlaps Z. 2014. Outcome study of 87 patients with late stage oral cancers. $12^{\text {th }}$ Joint Symposium Riga-Rostok Head and Neck oncology: Treatment and reconstruction Options.

Pastars, K., Tārs, J., Zariņš, J., Ivanova, A., Keirāns, A., Pauliṇa, B., Pīlaps Z. 2014. Reconstruction of esophagus with vascularised segment of intestine; late results (3 years follow up). 12 $2^{\text {th }}$ Joint Symposium Riga-Rostok Head and Neck oncology: Treatment and reconstruction Options. 
Pastars, K. 2011. Reconstructive and aesthetic surgery of the head and neck. Joint meeting of Latvian association of plastic surgeons and Latvian association of oral and maxillofacial surgeons.

Keirans, A., Pastars, K., Zarins J., Pilaps, Z., Tars, J., Ivanova, A., Paulina, B. 2014. Radial forearm flap versus lateral arm flap for oral cavity reconstruction. $12^{\text {th }}$ Joint Symposium Riga-Rostok Head and Neck oncology: Treatment and reconstruction Options.

Zarins, J., Pastars, K., Tārs, J., Keirans, A., Ivanova, A., Paulina, B., Pilaps, Z. 2014. Assessment of quality of life after late stage oral cavity cancer reconstruction with free flaps. $12^{\text {th }}$ Joint Symposium Riga-Rostok Head and Neck oncology: Treatment and reconstruction Options.

Bigestans, A., Salms, G., Skagers, A., Pastars, K., Kapickis, M. 2014. Case report: Treatment of fibrous dysplasia of the mandibule. $12^{\text {th }}$ Joint Symposium Riga-Rostok Head and Neck oncology: Treatment and reconstruction Options.

Kornevs, E., Tars, J. Lauskis, G., Kazanceva, A., Pastars, K., Paulina, B., Krastina A. 2014. Metastatic tumours of the parotid gland: Review of 20 years. $12^{\text {th }}$ Joint Symposium Riga-Rostok Head and Neck oncology: Treatment and reconstruction Options.

Pastars, K., Tārs, J. , Ivanova, A., Zariņš, J., Keirāns, A., Sīvins, A., Januskevics V. 2013. Esophageal reconstruction with vascularised intestine. $8^{\text {th }}$ congress of Baltic association for maxillofacial and plastic surgery.

Zariņš, J., Pastars, K., Keirāns, A., Tārs, J., Ivanova A. 2013. Outcomne study of 87 patients with late stage oral cavity cancers: reconstruction, recurrence, survival rate and quality of life. $8^{\text {th }}$ congress of Baltic association for maxillofacial and plastic surgery. 
Ivanova, A., Groma, V., Tars, J., Pastars, K., Korņevs, E., Liepa Z. 2011. Management of advanced SCC of the head and neck. $5^{\text {th }}$ Baltic Otorhinolaryngology Congress.

Ivanova, A., Groma, V., Tars, J., Pastars, K., Korņevs, E., Nora-Krukla, Z., Murovska, M. 2011. Epstein-Barr virus, Human herpes virus 6 and human herpes virus 7 association with oral squamous cell carcinoma and nasopharyngeal carcinoma. $5^{\text {th }}$ Baltic Otorhinolaryngplogy Congress.

Kazanceva, A., Groma, V., Korņevs, E., Tars, J., Pastars, K., Keirans, A. 2010. Clinical results of 50 patients with head and neck reconstructions using microvascular flaps and bone grafts. $7^{\text {th }}$ Congress of Baltic Association for Maxillofacial and Plastic Surgery.

Kazanceva, A., Tars, J., Groma, V., Pastars, K., Keirans, A., Kornevs, E. 2009. Reconstructive Surgery in the Head and Neck Oncology. Pirmais Baltijas valstu rekonstruktīvās, rokas un estētiskās ķirurğijas iepazī̌̌anās kongress.

Pastars, K., Zarins, J., Tars, J. Complications of free lateral arm flap transfers: experience with 50 consecutive cases. Asian Pacific Federation of Societies for Surgery of the Hand 2017 (Indonesia).

Pastars, K. 2017. Rekonstruktīva mikroķirurǵija ielaistu mutes vēžu ārstēšanā. 8. Latvijas ārstu kongress. 


\section{IZMANTOTĀ LITERATŪRA}

1. Biglioli, F., Liviero, F., Frigerio, A., Rezzonico, A. and Brusati, R. 2006. Function of the sensate free forearm flap after partial glossectomy. Journal of CranioMaxillofacial Surgery, 34(6), 332-339.

2. Bittar R. F., Ferraro, H. P., Ribas, M. H.and Lehn, C. N. 2016. Predictive factors of occult neck metastasis in patients with oral squamous cell carcinoma. Brazilian Journal of Otorhinolaryngology, 82(5), 543-547.

3. Brouha, X. D. R., Tromp, D. M., Hordijk, G. J., Winnubst, J. A. M.and de Leeuw, J. R. J. 2005. Oral and pharyngeal cancer: Analysis of patient delay at different tumor stages. Head and Neck-Journal for the Sciences and Specialties of the Head and Neck, 27(11), 939-945.

4. Buchmann, L., Conlee, J., Hunt, J., Agarwal, J. and White, S. 2013. Psychosocial Distress is Prevalent in Head and Neck Cancer Patients. Laryngoscope, 123(6), 1424-1429.

5. Chen, C. J., Zhang, Z. Y., Gao, S. P., Jiang, X. Q. and Zhang, Z. H. 2002. Speech after partial glossectomy: A comparison between reconstruction and nonreconstruction patients. Journal of Oral and Maxillofacial Surgery, 60(4), 404407.

6. Chen, W. C., Lai, C. H., Fang, C. C., Yang, Y. H., Chen, P. C., Lee, C. P. and Chen, M. F. 2016. Identification of High-Risk Subgroups of Patients With Oral Cavity Cancer in Need of Postoperative Adjuvant Radiotherapy or Chemo-Radiotherapy. Medicine, 95(22).

7. Cheraghlou, S., Kuo, P., Mehra, S., Yarbrough, W. G. and Judson, B. L. 2018. Untreated oral cavity cancer: Long-term survival and factors associated with treatment refusal. Laryngoscope, 128(3), 664-669.

8. Fakih, A. R., Rao, R. S., Borges, A. M. and Patel, A. R. 1989. Elective versus therapeutic neck dissection in early carcinoma of the oral tongue. The American Journal of Surgery, 158(4), 309-313.

9. Frampton, M. 2001. Psychological distress in patients with head and neck cancer: review. British Journal of Oral \& Maxillofacial Surgery, 39(1), 67-70.

10. Franceschi, D., Gupta, R., Spiro, R. H. and Shah, J. P. 1993. Improved survival in the treatment of squamous carcinoma of the oral tongue. American Journal of Surgery, 166(4), 360-365.

11. Gerressen, M., Pastaschek, C. I., Riediger, D., Hilgers, R. D., Holzle, F., Noroozi, N. and Ghassemi, A. 2013. Microsurgical Free Flap Reconstructions of Head and Neck Region in 406 Cases: A 13-Year Experience. Journal of Oral and Maxillofacial Surgery, 71(3), 628-635.

12. Gobbo, M., Bullo, F., Perinetti, G., Gatto, A., Ottaviani, G., Biasotto, M. and Tirelli, G. 2016. Diagnostic and therapeutic features associated with modification of 
quality-of-life's outcomes between one and six months after major surgery for head and neck cancer. Brazilian Journal of Otorhinolaryngology, 82(5), 548-557.

13. Gorsky, M. and Dayan, D. 1995. Referral delay in diagnosis of oro/oropharyngeal cancer in Israel. Oral Oncology-European Journal of Cancer Part B, 31B(3), 166168.

14. Grohmann, I., Raith, S., Muecke, T., Stimmer, H., Rohleder, N., Kesting, M. R., Holzle, F. and Steiner, T. 2015. Biomechanical loading test on reconstructed mandibles with fibular, iliac crest or scapula graft: a comparative study. British Journal of Oral \& Maxillofacial Surgery, 53(8), 741-747.

15. Hsiao, H. T., Leu, Y. S. and Lin, C. C. 2003. Tongue reconstruction with free radial forearm flap after hemiglossectomy: A functional assessment. Journal of Reconstructive Microsurgery, 19(3), 137-142.

16. Huang, S. H. and O'Sullivan, B. (2013). Oral cancer: Current role of radiotherapy and chemotherapy. Medicina Oral Patologia Oral Y Cirugia Bucal, 18(2), E233E240.

17. Huang, S. H. and O'Sullivan, B. 2017. Overview of the 8th Edition TNM Classification for Head and Neck Cancer. Current Treatment Options in Oncology, 18(7).

18. Jemal, A. 2011. Global Cancer Statistics (Vol 61, 69, 2011). Ca-a Cancer Journal for Clinicians, 61(2), 134-134.

19. Junior, R., Barboza, C. A. G., Clebis, N. K., de Moura, S. A. and Costa, A. D. L. 2008. Prognostic significance of the anatomical location and TNM clinical classification in oral squamous cell carcinoma. Medicina Oral Patologia Oral Y Cirugia Bucal, 13(6), E344-E347.

20. Klozar, J., Lischkeova B. and Betka, J. 2001. Subjective functional results 1 year after surgery and postoperative radiation for oropharyngeal carcinoma. European Archives of Oto-Rhino-Laryngology, 258(10), 546-551.

21. Kumar, M., Nanavati, R., Modi, T. G. and Dobariya, C. 2016. Oral cancer: Etiology and risk factors: A review. Journal of Cancer Research and Therapeutics, 12(2), 458-463.

22. Kumar, V. V., Kumar, U., Pillai, V., Ponnusamy, V., Al-Nawas, B. and Kuriakose, M. A. 2017. Implant Stability and Bone Characteristics in Free Fibula Flaps Used for Jaw Reconstruction: A Prospective Cohort Study. International Journal of Oral \& Maxillofacial Implants, 32(5), 1145-1152.

23. Lambert, R., Sauvaget, C., Cancela, M. D. and Sankaranarayanan, R. 2011. Epidemiology of cancer from the oral cavity and oropharynx. European Journal of Gastroenterology \& Hepatology, 23(8), 633-641.

24. Le Campion, A. C. O. V., Ribeiro, C. M. B., Luiz, R. R., da Silva Júnior, F. F., Barros, H. C. S., Dos Santos, K. C. B., Ferreira, S. J., Gonçalves, L. S. and Ferreira, 
S. M. S. 2017. Low Survival Rates of Oral and Oropharyngeal Squamous Cell Carcinoma. Int J Dent, 2017: 5815493.

25. Leon, X., Martinez, V., Lopez, M., Garcia, J., del Prado Venegas, M., Esteller, E. and Quer, M. 2012. Second, third, and fourth head and neck tumors. A progressive decrease in survival. Head and Neck-Journal for the Sciences and Specialties of the Head and Neck, 34(12), 1716-1719.

26. Liang, J. W., Yu, T., Wang, X., Zhao, Y. J., Fang, F. Q., Zeng, W. and Li, Z. D. 2018. Free tissue flaps in head and neck reconstruction: clinical application and analysis of 93 patients of a single institution. Brazilian Journal of Otorhinolaryngology, 84(4), 416-425

27. Lin, C. S., Jen, Y. M., Kao, W. Y., Ho, C. L., Dai, M. S., Shih, C. L., Cheng, J. C., Chang, P. Y., Huang, W. Y. and Su, Y. F. 2013. Improved outcomes in buccal squamous cell carcinoma. Head Neck, 35(1), 65-71.

28. Lodders, J. N., Schulten, E., de Visscher, J., Forouzanfar, T. and Karagozoglu, K. H. 2016. Complications and Risk after Mandibular Reconstruction with Fibular Free Flaps in Patients with Oral Squamous Cell Carcinoma: A Retrospective Cohort Study. Journal of Reconstructive Microsurgery, 32(6), 455-463.

29. Loeffelbein, D. J., Julinek, A., Wolff, K. D., Kochs, E., Haller, B. and Haseneder, R. 2016. Perioperative risk factors for postoperative pulmonary complications after major oral and maxillofacial surgery with microvascular reconstruction: A retrospective analysis of 648 cases. Journal of Cranio-Maxillofacial Surgery, 44(8), 952-957.

30. Lonie, S., Herle, P., Paddle, A., Pradhan, N., Birch, T. and Shayan, R. 2016. Mandibular reconstruction: meta-analysis of iliac- versus fibula-free flaps. Anz Journal of Surgery, 86(5), 337-342.

31. Lopez-Arcas, J. M., Arias, J., Del Castillo, J. L., Burgueno, M., Navarro, I., Moran, M. J., Chamorro, M. and Martorell, V. 2010. The Fibula Osteomyocutaneous Flap for Mandible Reconstruction: A 15-Year Experience. Journal of Oral and Maxillofacial Surgery, 68(10), 2377-2384.

32. López-Cedrún, J. L. and Andrés de Llano, J. 2015. A 22 years survival and prognostic factors analysis in a homogeneous series of 64 patients with advanced cancer of the tongue and the floor of the mouth. J Craniomaxillofac Surg, 43(3), 376-381.

33. Luryi, A. L., Chen, M. M., Mehra, S., Roman, S. A., Sosa, J. A. and Judson, B. L. 2014. Positive Surgical Margins in Early Stage Oral Cavity Cancer: An Analysis of 20,602 Cases. Otolaryngology-Head and Neck Surgery, 151(6), 984-990.

34. Maldonado, A. A. and Langerman, A. 2017. Fibula osteofascial flap with proximal skin paddle for intraoral reconstruction. Microsurgery, 37(4), 276-281.

35. Matsui, Y., Ohno, K., Yamashita, Y. and Takahashi, K. 2007. Factors influencing postoperative speech function of tongue cancer patients following reconstruction 
with fasciocutaneous/myocutaneous flaps - a multicenter study. International Journal of Oral and Maxillofacial Surgery, 36(7), 601-609.

36. Milet, P. R., Mallet, Y., El Bedoui, S., Penel, N., Servent, V. and Lefebvre, J. L. 2010. Head and neck cancer surgery in the elderly - Does age influence the postoperative course? Oral Oncology, 46(2), 92-95.

37. Montero, P. H. and Patel, S. G. 2015. Cancer of the oral cavity. Surg Oncol Clin N Am, 24(3), 491-508.

38. Morelatto, R. A., Herrera, M. C., Fernandez, E. N., Corball, A. G. and Lopez De Blanc, S. A. 2007. Diagnostic delay of oral squamous cell carcinoma in two diagnosis centers in Cordoba Argentina. Journal of Oral Pathology \& Medicine, 36(7), 405-408.

39. Mulvey, C. L., Brant, J. A., Bur, A. M., Chen, J. B., Fischer, J. P., Cannady, S. B. and Newman, J. G. 2017. Complications Associated with Mortality after Head and Neck Surgery: An Analysis of the NSQIP Database. Otolaryngology-Head and Neck Surgery, 156(3), 504-510.

40. Murphy, B. A., Ridner, S., Wells, N. and Dietrich, M. 2007. Quality of life research in head and neck cancer: A review of the current state of the science. Critical Reviews in Oncology Hematology, 62(3), 251-267.

41. Noguti, J., De Moura, C. F. G., De Jesus, G. P. P., Da Silva, V. H. P., Hossaka, T. A., Oshima, C. T. F. and Ribeiro, D. A. 2012. Metastasis from Oral Cancer: An Overview. Cancer Genomics \& Proteomics, 9(5), 329-335.

42. Onizawa, K., Nishihara, K., Yamagata, K., Yusa, H., Yanagawa, T. and Yoshida, H. 2003. Factors associated with diagnostic delay of oral squamous cell carcinoma. Oral Oncology, 39(8), 781-788.

43. Patel, U. A., Hartig, G. K., Hanasono, M. M., Lin, D. T. and Richmon, J. D. 2017. Locoregional Flaps for Oral Cavity Reconstruction: A Review of Modern Options. Otolaryngology-Head and Neck Surgery (United States), 157(2), 201-209.

44. Pollei, T. R., Hinni, M. L., Moore, E. J., Hayden, R. E., Olsen, K. D., Casler, J. D. and Walter, L. C. 2013. Analysis of Postoperative Bleeding and Risk Factors in Transoral Surgery of the Oropharynx. Jama Otolaryngology-Head \& Neck Surgery, 139(11), 1212-1218.

45. Punhani, N., Dongarwar, G. R., Mahajan, H., Daniel, M. J., Chalapathi, K. V. and Nayyar, A. S. 2017. Tumor Size and Its Relation to Cervical Lymph Node Metastasis and Its Significance as a Prognostic Indicator for Oral Squamous Cell Carcinomas. Clinical Cancer Investigation Journal, 6(3), 153-166.

46. Rathod, S., Livergant, J., Klein, J., Witterick, I. and Ringash, J. 2015. A systematic review of quality of life in head and neck cancer treated with surgery with or without adjuvant treatment. Oral Oncol, 51(10), 888-900. 
47. Rogers, S. N., Fisher, S. E. and J. A. Woolgar 1999. A review of quality of life assessment in oral cancer. International Journal of Oral and Maxillofacial Surgery, 28(2), 99-117.

48. Rogers, S. N., Lowe, D., Brown, J. S. and Vaughan, E. D. 1999. The University of Washington head and neck cancer measure as a predictor of outcome following primary surgery for oral cancer. Head and Neck-Journal for the Sciences and Specialties of the Head and Neck, 21(5), 394-401.

49. Rogers, S. N., Lowe, D., Fisher, S. E., Brown, J. S. and Vaughan, E. D. 2002. Health-related quality of life and clinical function after primary surgery for oral cancer. British Journal of Oral \& Maxillofacial Surgery, 40(1), 11-18.

50. Rogers, S. N., Miller, R. D., Ali, K., Minhas, A. B., Williams, H. F. and Lowe D. 2006. Patients' perceived health status following primary surgery for oral and oropharyngeal cancer. International Journal of Oral and Maxillofacial Surgery, 35(10), 913-919.

51. Rubright, W. C., Hoffman, H. T., Lynch, C. F., Kohout, F. J., Robinson, R. A., Graham, S., Funk G. and McCulloch T. 1996. Risk factors for advanced-stage oral cavity cancer. Archives of Otolaryngology-Head \& Neck Surgery, 122(6), 621-626.

52. Schneider, I. J., Flores, M. E., Nickel, D. A., Martins, L. G. and Traebert J. 2014. Survival rates of patients with cancer of the lip, mouth and pharynx: a cohort study of 10 years. Rev Bras Epidemiol, 17(3), 680-691.

53. Scully, C. and Bagan, J. 2009. Oral squamous cell carcinoma overview. Oral Oncology, 45(4), 301-308.

54. Sessions, D. G., Spector, G. J., Lenox, J., Haughey, B., Chao, C. and Marks, J. 2002. Analysis of treatment results for oral tongue cancer. Laryngoscope, 112(4), 616625 .

55. Sessions, D. G., Spector, G. J., Lenox, J., Parriott, S., Haughey, B., Chao, C., Marks, J. and Perez, C. 2000. Analysis of treatment results for floor-of-mouth cancer. Laryngoscope, 110(10), 1764-1772.

56. Shah, J. P., Candela, F. C. and Poddar, A. K. 1990. The patterns of cervical lymph node metastases from squamous carcinoma of the oral cavity. Cancer, 66(1), 109113.

57. Shah, J. P. and Gil, Z. 2009. Current concepts in management of oral cancer Surgery. Oral Oncology, 45(4-5), 394-401.

58. Shroff, S. S., Nair, S. C., Shah, A. and Kumar B. 2017. Versatility of Fibula Free Flap in Reconstruction of Facial Defects: A Center Study. Journal of Maxillofacial \& Oral Surgery, 16(1), 101-107.

59. Smee, R. I., Broadley, K., Bridger, G. P. and Williams, J. 2012. Floor of mouth carcinoma: Surgery still the dominant mode of treatment. Journal of Medical Imaging and Radiation Oncology, 56(3), 338-346. 
60. Stathopoulos, P. and Smith, W. 2017. Analysis of Survival Rates Following Primary Surgery of 178 Consecutive Patients with Oral Cancer in a Large District General Hospital. Journal of Maxillofacial \& Oral Surgery, 16(2), 158163.

61. Sugiura, Y., Sarukawa, S., Hayasaka, J., Kamochi, H., Noguchi, T. and Mori Y. 2018. Mandibular reconstruction with free fibula flaps in the elderly: a retrospective evaluation. International Journal of Oral and Maxillofacial Surgery, 47(8), 983-989.

62. Swanson, E., Boyd, J. B. and Manktelow, R. T. 1990. The radial forearm flap: Reconstructive applications and donor-site defects in 35 consecutive patients. Plastic and Reconstructive Surgery, 85(2), 258-266.

63. Tangthongkum, M., Kirtsreesakul, V., Supanimitjaroenporn, P. and Leelasawatsuk, P. 2017. Treatment outcome of advance staged oral cavity cancer: concurrent chemoradiotherapy compared with primary surgery. Eur Arch Otorhinolaryngol, 274(6), 2567-2572.

64. Tsai, C. H., Chang, K. P., Hung, S. Y., Chen, W. F., Cheng, M. H. and Kao, H. K. 2012. Postoperative morbidity in head and neck cancer ablative surgery followed by microsurgical free tissue transfer in the elderly. Oral Oncology, 48(9), 811-816.

65. Weatherspoon, D. J., Chattopadhyay, A., Boroumand, S. and Garcia, I. 2015. Oral cavity and oropharyngeal cancer incidence trends and disparities in the United States: 2000-2010. Cancer Epidemiology, 39(4), 497-504.

66. Xu, Z. F., Bai, S., Zhang, Z. Q., Duan, W. Y., Wang, Z. Q. and Sun, C. F. 2017. A critical assessment of the fibula flap donor site. Head and Neck-Journal for the Sciences and Specialties of the Head and Neck, 39(2), 279-287.

67. Zhou, W., Zhang, W. B., Yu, Y., Wang, Y., Mao, C., Guo, C. B., Yu, G. Y. and Peng, X. 2017. Risk factors for free flap failure: a retrospective analysis of 881 free flaps for head and neck defect reconstruction. International Journal of Oral and Maxillofacial Surgery, 46(8), 941-945. 


\section{PATEICĪBAS}

Izsaku pateicību darba vadītājam prof. Andrejam Skaǵeram par darba vadīšanu, atbalstu, padomiem un pacietību darba tapšanā.

Paldies doc. Annai Ivanovai par nemitīgu un neatlaidīgu uzstājību sākt pētniecisko darbu un nesavtīgu atbalstu pētījuma tapšanas laikā.

Liels paldies LOC Galvas un kakla ķirurǵijas nodaļas vadītājam Jurim Tāram par iespēju atvērt jaunu lappusi Latvijas galvas un kakla ķirurǵijas sadaḷā.

Paldies Mikroķirurğijas centra kolēgiem par atbalstu visneiedomājamākajos veidos pētījuma veikšanā.

Paldies Ilzei Mutulei, bez vinas atbalsta un palīdzības to paveikt nebūtu iespējams.

Un visbeidzot liels paldies manai mịlajai gimenei par iecietību un sapratni. 